\title{
9. OLIGOCENE PLANKTONIC FORAMINIFER BIOSTRATIGRAPHY OF HOLE 803D (ONTONG JAVA PLATEAU) AND HOLE 628A (LITTLE BAHAMA BANK), AND COMPARISON WITH THE SOUTHERN HIGH LATITUDES ${ }^{1}$
}

\author{
R. Mark Leckie, ${ }^{2}$ Christie Farnham,${ }^{3}$ and Maxine G. Schmidt ${ }^{2}$
}

\begin{abstract}
Ocean Drilling Program Hole 803D (Leg 130) from the western tropical Pacific (Ontong Java Plateau) and Hole 628A (Leg 101) from the western subtropical North Atlantic (Little Bahama Bank) contain rich assemblages of planktonic foraminifers. The uppermost Eocene-basal Miocene section of Hole 803D is apparently complete, whereas the Oligocene section of Hole 628A contains three unconformities based on planktonic foraminiferal evidence. Anomalous ranges are recorded for Chiloguembelina cubensis and Globigerinoides primordius. C. cubensis is found to range throughout the upper Oligocene of both sites, and G. primordius first occurs near the base of upper Oligocene Zone P22 in Hole 628A. Paleomagnetic stratigraphy provides constraints on the last occurrence (LO) of Subbotina angiporoides, the first occurrence (FO) of Globigerina angulisuturalis, the FO of Globigerinoides primordius, the FO of Paragloborotalia pseudokugleri, and the LO of Chiloguembelina cubensis.

In general, taxon ranges, total diversity, and the composition of the planktonic foraminiferal assemblages from Holes 628A and 803D are similar. Differences in the composition of planktonic foraminiferal assemblages between the two sites are interpreted to be primarily the result of enhanced dissolution at Site 803 (e.g., paucity of Globigerina angulisuturalis and absence of G. ciperoensis). However, the greater abundances of Subbotina angiporoides in subtropical Hole 628A and Paragloborotalia opima in tropical Hole 803D are probably related to oceanographic differences between the two low-latitude sites. Comparison between the low and southern high latitudes illustrates some similarities in the composition of Oligocene planktonic foraminiferal assemblages as well as some important differences. Species such as Pseudohastigerina spp., Turborotalia increbescens, "Turborotalia" ampliapertura, Paragloborotalia opima, P. pseudokugleri, P. semivera/mayeri, Globigerinella obesa, Globigerina angulisuturalis, G. gortanii, G. ouachitaensis, G. sellii, G. tapuriensis, G. tripartita, G. pseudovenezuelana, Subbotina? eocaena and S.? yeguaensis are absent or have rare occurrences in the subantarctic Oligocene assemblages. Biogeographic gradients, although not as pronounced as during the late Neogene, were nonetheless significant during the Oligocene.
\end{abstract}

\section{INTRODUCTION}

The stratigraphic record of the Oligocene contains valuable information about changing climatic and oceanographic conditions as the high latitudes cooled and ice caps formed on the continent of Antarctica. In latest Eocene/earliest Oligocene time, a major cooling step is recorded in the oxygen isotopes of benthic foraminifers as cold deep-water masses filled the ocean basins (e.g., Savin et al., 1975; Shackleton and Kennett, 1975; Kennett and Shackleton, 1976; Boersma and Shackleton, 1977; Keigwin, 1980; Matthews and Poore, 1980; Miller and Curry, 1982; Corliss et al., 1984; Miller and Fairbanks, 1985). The initiation of pyschrospheric circulation in the Oligocene represents the transition from an Eocene mode of deepwater formation to a Neogene mode similar to today's circulation (Kennett and Stott, 1990, 1991). Additional significant cooling steps are also recorded in the mid- and latest Oligocene (Keigwin and Keller, 1984; Miller et al., 1987, 1988). The mid-Oligocene step was associated with a major drop in eustatic sea level (Haq et al., 1987).

The plankton also record changing oceanographic and climatic conditions during the Oligocene as meridional temperature gradients decreased, biogeographic provinces broadened and became fewer in number, and planktonic foraminiferal faunas became more generalized (e.g., Cifelli, 1969; Haq et al., 1977; Kennett, 1977, 1978). Although planktonic foraminiferal diversity was relatively low during Oligocene time and the biogeographic ranges of many species expanded, important differences remained in assemblage diversity and composition between low and high latitudes, and between ocean basins. In addition,

\footnotetext{
${ }^{1}$ Berger, W.H., Kroenke, L.W., Mayer, L.A., et al., 1993. Proc. ODP, Sci. Results, 130: College Station, TX (Ocean Drilling Program).

${ }^{2}$ Department of Geology and Geography, University of Massachusetts, Amherst, MA 01003, U.S.A.

${ }^{3}$ Department of Geology, Duke University, Durham, NC 27706, U.S.A.
}

taxon first and last occurrences in the Oligocene may be highly diachronous between ocean basins, even within an ocean basin, as recently shown by Hess et al. (1989).

We have examined two low-latitude Oligocene sections, one from the tropical western Pacific (Ocean Drilling Program [ODP] Leg 130, Hole $803 \mathrm{D}$ ) and one from the subtropical western North Atlantic (ODP Leg 101, Hole 628A) (Fig. 1). Both sites contain rich assemblages of planktonic foraminifers. Recent ODP drilling in the southern high latitudes has provided new Oligocene records of planktonic foraminiferal populations for comparison with our low-latitude results (e.g., Stott and Kennett, 1990; Huber, 1991; Nocchi et al., 1991). Our purpose here is to document planktonic foraminiferal distribution through the uppermost Eocene-basal Miocene interval of Holes $628 \mathrm{~A}$ and $803 \mathrm{D}$, to compare assemblage composition between these two low-latitude sites, and to examine the similarities and differences in assemblage composition between the low latitudes and southern high latitudes based on recent ODP results. In addition, we have tried to clarify the species concepts of many of the low-latitude Oligocene taxa by comparing each with related taxa, and by illustrating some of the range of morphologic variability within each taxon.

\section{METHODS}

A total of 129 samples were examined for planktonic foraminifers in Holes 628A and 803D. Samples were soaked in a neutral $\mathrm{pH}$ mixture of diluted hydrogen peroxide and Calgon for an hour or so. Chalky samples were ultrasonicated for $10-15 \mathrm{~s}$. The sediment was washed over a $63 \mu \mathrm{m}$ sieve. Small bits of chalk were carefully squeezed between the finger tips to enhance disaggregation. This physical manipulation of the sediments did not result in enhanced breakage of foraminiferal tests. The samples were then dried in an oven. Nearly all samples had to be washed twice to free the foraminifer tests from the chalky matrix. 


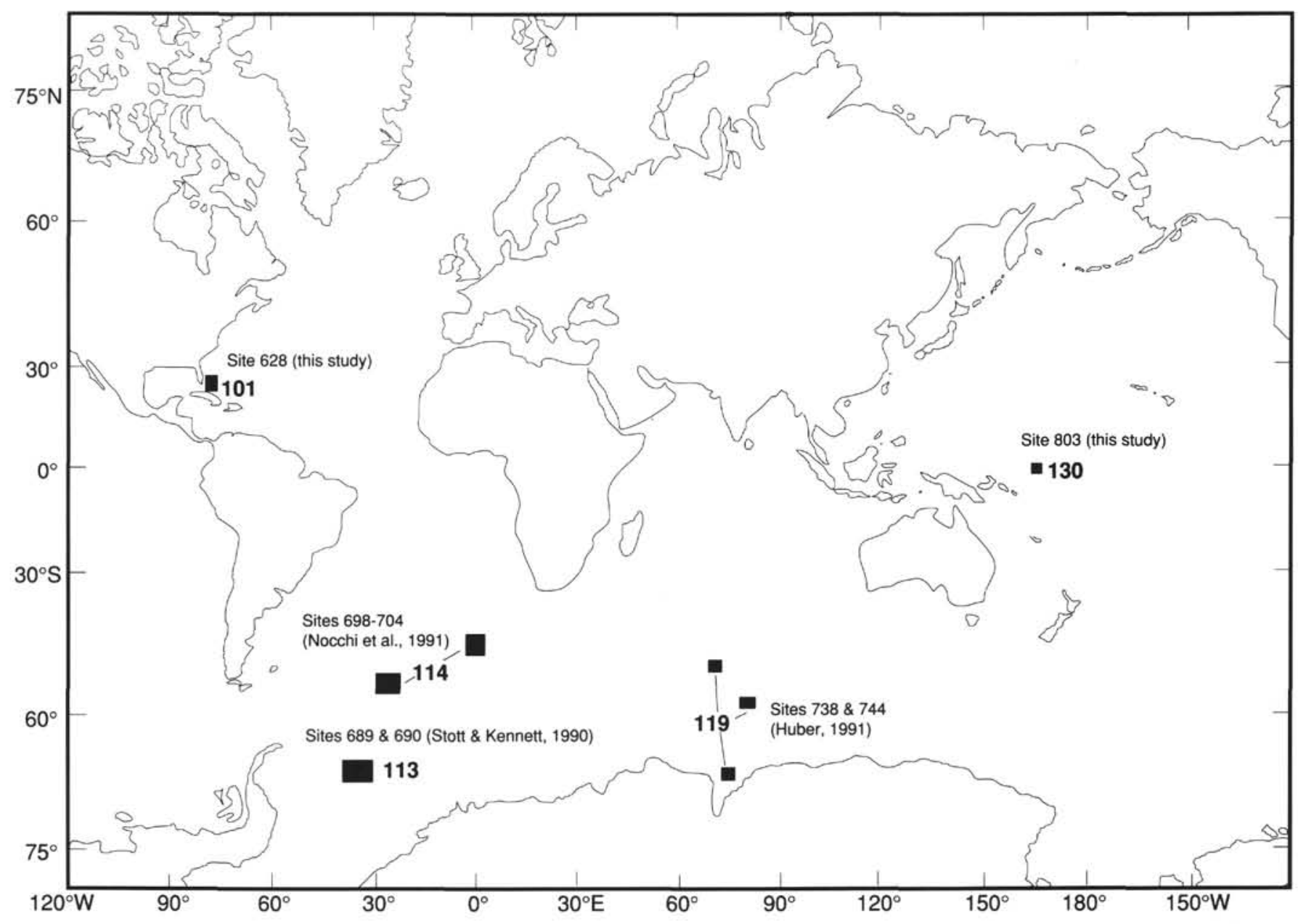

Figure 1. Map showing the location of ODP Sites 628 (Little Bahama Bank, Leg 101) and 803 (Ontong Java Plateau, Leg 130), and the location of the southern high-latitude ODP sites discussed in the text (Maud Rise, Leg 113; South Atlantic transect, Leg 114; and southern flank of the Kerguelen Plateau, Leg 119).

The disaggregated sediment was sprinkled on a picking tray, and individual specimens were picked and mounted on a gummed population slide. All samples were examined at least twice. Relative abundance data was based on the $>63 \mu \mathrm{m}$ fraction, although the $>250 \mu \mathrm{m}, 150-250 \mu \mathrm{m}$, and 63-150 $\mu \mathrm{m}$ fractions were also examined for rare species. Two categories of foraminiferal species abundance were recorded; rare $=<5 \%$, and few to common $=>5 \%$. Foraminiferal preservation was based on a qualitative assessment of the degree of test breakage and/or dissolution. The relative abundance of radiolarians was also noted.

\section{HOLE 628A (LITTLE BAHAMA BANK)}

Hole $628 \mathrm{~A}\left(27^{\circ} 38.10^{\prime} \mathrm{N}, 78^{\circ} 18.95^{\prime} \mathrm{W}\right)$ was drilled on Little Bahama Bank in the western North Atlantic in a water depth of $966 \mathrm{~m}$ (Austin, Schlager, Palmer, et al., 1986). We examined 42 samples from Cores 101-628A-16H through -29X for planktonic foraminifers (Fig. 2). This interval represents the uppermost Eocene (Zone P17) through Oligocene (Zone P22). The uppermost Oligocene is truncated by an unconformity; sediments of middle Miocene Zone N12 overlie sediments of uppermost Zone P22 (the unconformity occurs in the coring break between Cores 101-628A-15H and -16H). Foraminiferal preservation is moderately good to good in most of the samples examined, and radiolarian abundance is low.

Three unconformities were recognized in the Oligocene section based on planktonic foraminiferal evidence: P22/P21a, P21a/P19, and P19/P18 (Fig. 2). These unconformities are associated with an interval of interbedded calcareous ooze and chalk, foraminifernannofossil ooze and chalk, and unlithified packstone and floatstone in Cores 101-628A-24X through -26X. The bulk of the Oligocene section is composed of nannofossil ooze and chalk and foraminifernannofossil ooze and chalk in Cores 101-628A-16H through -23X, and calcareous ooze and chalk in Cores 101-628A-27X and -28X. Core 101-628A-29X (uppermost Eocene) consists of nannofossil ooze. The change in lithology across the Eocene/Oligocene boundary raises the possibility that another unconformity may be present in the coring break between Cores 101-628A-28X and -29X, although there is no compelling planktonic foraminiferal evidence for an unconformity through this interval. The evidence for the unconformities is discussed in the "Biostratigraphy" section (this chapter).

Sager (1988) established the paleomagnetic stratigraphy for the Oligocene of Hole 628A, although we have reinterpreted this record based on the planktonic foraminiferal biostratigraphy presented below (Fig. 2). The paleolatitude of Site 628 during the Oligocene was $25.8^{\circ} \mathrm{N}$ (Sager, 1988).

\section{HOLE 803D (ONTONG JAVA PLATEAU)}

Hole $803 \mathrm{D}\left(2^{\circ} 25.98^{\prime} \mathrm{N}, 160^{\circ} 32.46^{\prime} \mathrm{E}\right)$ was drilled on the Ontong Java Plateau in the western equatorial Pacific in a water depth of $3412 \mathrm{~m}$ (Kroenke, Berger, Janecek, et al., 1991). We examined 87 samples from Cores $130-803 \mathrm{D}-35 \mathrm{X}$ through $-60 \mathrm{X}$ for planktonic foraminifers 


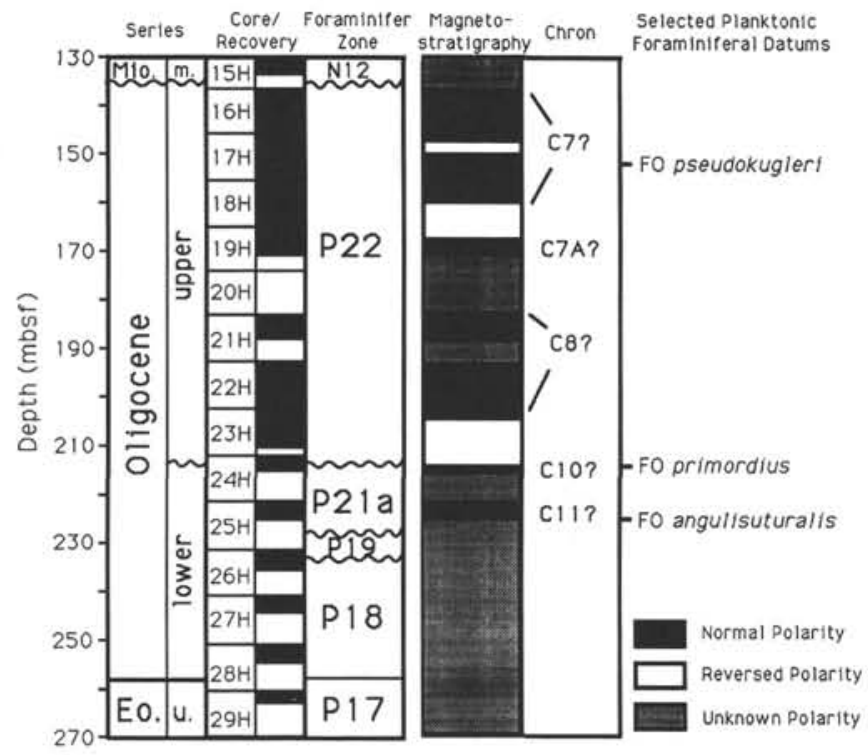

Figure 2. Planktonic foraminiferal biostratigraphy and magnetostratigraphy of the uppermost Eocene and Oligocene from Hole 628A. Magnetostratigraphy is from Sager (1988). Paleomagnetic chrons have been reinterpreted based on the planktonic foraminiferal evidence presented here. Selected planktonic foraminiferal first (FO) and last (LO) occurrences with correlation to the paleomagnetic record are shown. Scale to the left corresponds to meters below seafloor.

(Fig. 3). This interval represents the uppermost Eocene (Zone P17) through basal Miocene (basal Zone N4). The section appears to be complete based on the planktonic foraminiferal evidence. The bulk of the section is composed of nannofossil chalk. Foraminiferal preservation ranges from moderately good to poor. The sediments have probably experienced some dissolution, based on foraminiferal preservation and the abundance of radiolarians.

A preliminary shipboard paleomagnetic stratigraphy was established for the Oligocene of Hole 803D by Musgrave and Tarduno (in Kroenke, Berger, Janecek, et al., 1991, pp. 130-134) (Fig. 3). They concluded that Site 803 was at a paleolatitude of about $4.5^{\circ} \mathrm{S}$ during the Oligocene.

\section{BIOSTRATIGRAPHY}

\section{Zonal Criteria, Taxon Ranges, and Unconformities}

We have followed the tropical Paleogene planktonic foraminiferal biostratigraphic zonation of Berggren and Miller (1988) (Fig. 4). The uppermost Eocene to lowermost Miocene part of this zonal scheme represents a revision of earlier zonal criteria by Bolli (1957a, 1957b, 1966), Berggren (1969), Blow (1969), Stainforth et al. (1975), Poore (1984), Bolli and Saunders (1985), and Toumarkine and Luterbacher (1985) (Fig. 4). Berggren and Miller (1988) have separated zonal criteria into two categories: those with well-known magnetochronologic age estimates (after Berggren et al., 1985) and those with age estimates based on biochronology. Our work on the Oligocene of Holes $628 \mathrm{~A}$ and $803 \mathrm{D}$ calls into question the magnetochronologic age estimates of several taxa including the first occurrence (FO) of Globigerinoides primordius and the last occurrence (LO) of Chiloguembelina cubensis. These results are based on biostratigraphic and magnetostratigraphic evidence (Figs. 2 and 3 ).

The uppermost Eocene-basal Miocene sequence of Hole 803D is apparently complete based on the planktonic foraminiferal biostratigraphy and the lack of major changes in lithology. On the other hand, Hole $628 \mathrm{~A}$ contains three stratigraphic breaks within the Oligocene based on the planktonic foraminiferal biostratigraphy and lithology. In addition, the uppermost Oligocene is truncated by a major unconformity at this site. The evidence for these stratigraphic breaks is discussed below.

\author{
Turborotalia cerroazulensis Partial Range Zone \\ (Zone P17)
}

Definition: Partial range of the nominate taxon between the LO of Cribrohantkenina inflata (base) and the LO of T cerroazulensis s.l. (top).

Discussion: The LO of the $T$. cerroazulensis group is coincident with the LO of Hantkenina alabamensis at both sites. Preservation is moderately good in the uppermost Eocene of Hole 628A (Fig. 5). In this hole, the $T$. cerroazulensis group is represented by the subspecies T. cerroazulensis cunialensis, T. cerroazulensis cocoaensis, T. cerroazulensis cerroazulensis, and $T$. cerroazulensis pomeroli, as well as whole specimens of Hantkenina alabamensis. Preservation is poor in the uppermost Eocene of Hole 803D, and only rare specimens of T. cerroazulensis pomeroli and spines of Hantkenina are recorded in this interval (Fig. 6). Typical specimens of Pseudohastigerina micra are present through the uppermost Eocene of both sites.

The Eocene/Oligocene boundary interval in Hole 628A is assumed to be complete based on the planktonic foraminiferal biostratigraphy, but a change in lithology from nannofossil ooze in Core 101-628A-29X (uppermost Eocene) to calcareous ooze and chalk in Core 101-628A-28X (basal Oligocene) (Austin, Schlager, Palmer, et al., 1986) suggests the possibility of a stratigraphic break in this interval. The Eocene/Oligocene boundary in Hole 803D is also assumed to be complete, but a marked change in foraminiferal preservation is present across the boundary, from poor in the uppermost Eocene to moderately good in the basal Oligocene samples. Keller et al. (1987) show a widespread hiatus (PHc) in the basal Oligocene associated with the development of the psychrosphere.

\section{Chiloguembelina cubensis-Pseudohastigerina spp. Partial Range Zone (Zone P18)}

Definition: Concurrent partial ranges of the nominate taxa between the LO of Turborotalia cerroazulensis s.l. (base) and the LO of the Pseudohastigerina spp. group (top).

Discussion: Forms referable to Pseudohastigerina naguewichiensis and $P$. aff. micra characterize the basal Oligocene zone of both sites. Pseudohastigerina spp. occur persistently throughout Zone P18 and the extinction of the genus is a reliable datum at these sites (Figs. 5 and 6). Chiloguembelina cubensis is also a common constituent of the P18 assemblages. Cassigerinella chipolensis first occurs in the basal Oligocene sample of Hole 803D (130-803D-58X-CC), although its absence in the uppermost Eocene may be ascribed to dissolution at this site. The FO of $C$. chipolensis has been used by some workers to mark the base of the Oligocene (e.g., Bolli, 1957a, 1957b; Bolli and Saunders, 1985). However, $C$. chipolensis is present in the uppermost Eocene sediments of Hole 628A, suggesting that this taxon is not a reliable indicator of the Eocene/Oligocene boundary (see discussion in Berggren and Miller, 1988). Globigerina tapuriensis, although present at both sites, has a more persistent occurrence in Hole 803D. On the other hand, Subbotina angiporoides and S. linaperta s.1. are more common in Hole 628A. Globigerina tripartita first occurs in the basal Oligocene sample of both sites, and Turborotalia increbescens last occurs in the upper part of Zone P18.

An unconformity may separate Zones P18 and P19 in Hole 628A based on the LO of Pseudohastigerina spp. in Sample 101-628A26X-2, 102-104 cm, and the FO of Paragloborotalia opima in Sample 101-628A-26X-1, 74-76 cm (Fig. 5). Core 101-628A-26X contains interbedded foraminifer-nannofossil ooze and chalk, and unlithified packstone and floatstone (Austin, Schlager, Palmer, et al., 1986). A thick interval of packstone and floatstone occurs between these two samples, suggesting erosion and/or downslope transport. No major widespread hiatus event is present in this interval, according to an analysis of the global distribution of late Paleogene hiatuses by Keller et al. (1987). 


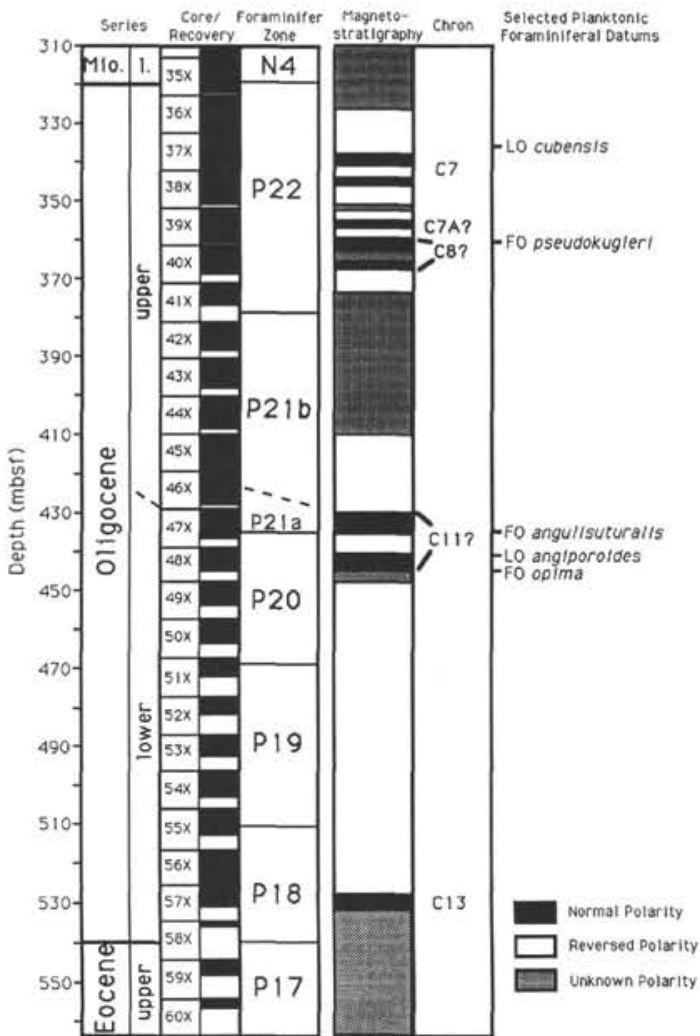

Figure 3. Planktonic foraminiferal biostratigraphy and magnetostratigraphy of the uppermost Eocene to basal Miocene from Hole 803D. Magnetostratigraphy is from Musgrave and Tarduno (in Kroenke, Berger, Janecek, et al., 1991). Selected planktonic foraminiferal first (FO) and last (LO) occurrences with correlation to the paleomagnetic record are shown. Scale to the left corresponds to meters below seafloor.

\section{"Turborotalia" ampliapertura Partial Range Zone (Zone P19)}

Definition: Partial range of the nominate taxon between the LO of Pseudohastigerina spp. group (base) and the LO of the nominate taxon (top).

Discussion: A fairly strict species concept is applied here to "Turborotalia" ampliapertura. This taxon is gradational with Globigerina euapertura. " $T$." ampliapertura is distinguished by its narrower and higher arched aperture. Paragloborotalia opima and Globigerina sellii both first occur in Zone P19 of Hole 628A, but they do not occur until Zone P20 of Hole 803D (Figs. 5 and 6).

An unconformity separates Zone P19 and Subzone P21a in Hole 628A based on the LO of in situ "Turborotalia" ampliapertura in Sample 101-628A-26X-1, 74-76 cm, and the FO of Globigerina angulisuturalis in Sample 101-628A-25X-CC (Fig. 5). In addition, reworked planktonic foraminifers from Zone P17 (and P18?) are present in Sample 101-628A-25X-CC. Core 101-628A-25X had only $37 \%$ recovery; interbedded foraminifer-nannofossil ooze and chalk, and unlithified packstone and floatstone were recovered in Core 101-628A-24X above and Core 101-628A-26X below (Austin, Schlager, Palmer, et al., 1986), suggesting an interval of erosion and/or downslope transport. This interval does not correspond with a peak in global hiatus distribution (Keller et al., 1987).

\section{Globigerina sellii Partial Range Zone (Zone P20)}

Definition: Partial range of the nominate taxon between the LO of "Turborotalia" ampliapertura (base) and the FO of Globigerina angulisuturalis (top).

Discussion: Zone P20 is not represented by the samples examined from Hole 628A because of the presence of an unconformity between Zone P19 and Subzone P21a. The FO of Paragloborotalia opima and

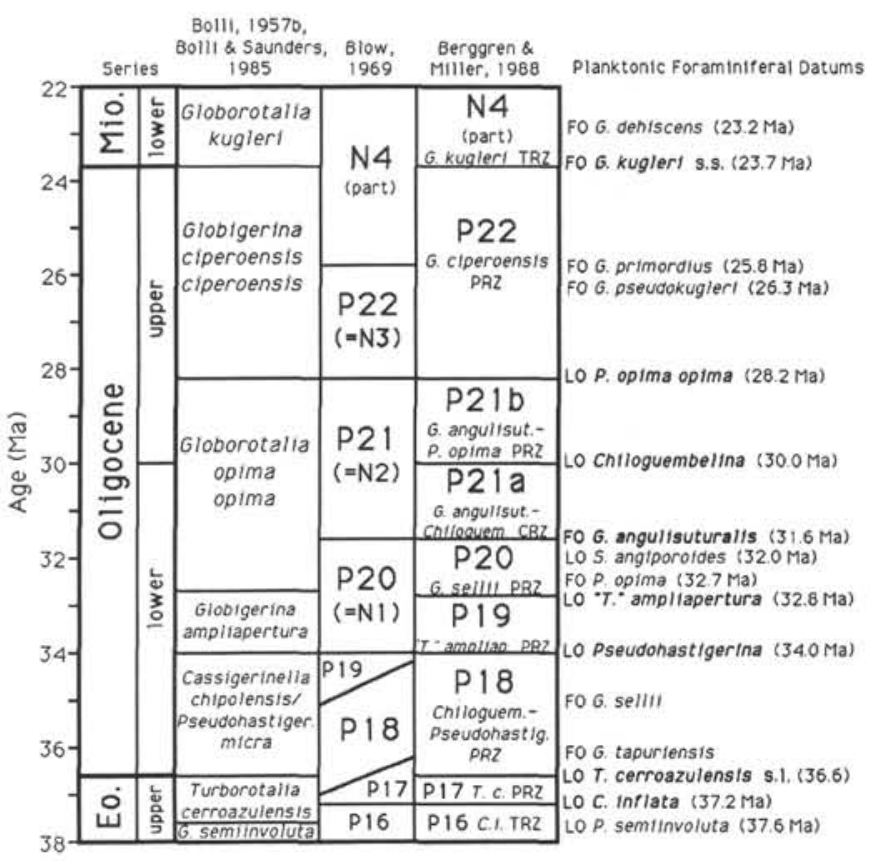

Figure 4. Planktonic foraminiferal zonation of the uppermost Eocene-basal Miocene interval used in this study. Ages of planktonic foraminiferal datums are from Berggren et al. (1985) and Berggren and Miller (1988).

the FO of Globigerina sellii are noted in the upper part of Zone P20 in Hole 803D, associated with the base of Chron C11 Normal (Figs. 3 and 6). The LO of Subbotina angiporoides is in the uppermost part of Zone P20 in Hole 803D, associated with the lower part of Chron $\mathrm{C} 11$ Normal, just below the FO of Globigerina angulisuturalis (see also Berggren et al., 1985; Berggren and Miller, 1988). Globigerina praebulloides first occurs near the base of Zone P20 in Hole 803D, but it is recorded in Zone P19 from Hole 628A.

\section{Globigerina angulisuturalis/Paragloborotalia opima Concurrent Range Zone (Zone P21)}

Definition: Concurrent range of nominate taxa between the FO of Globigerina angulisuturalis (base) and the LO of Paragloborotalia opima (top).

\section{Globigerina angulisuturalis/Chiloguembelina cubensis Concurrent Range Subzone (Subzone P21a)}

Amended definition: Concurrent range of the nominate taxa between the FO of Globigerina angulisuturalis (base) and the last "common" occurrence of Chiloguembelina cubensis (top).

Discussion: Globigerina angulisuturalis is a common taxon throughout Subzone P21 a of Hole 628A, but it occurs only rarely in Subzone $\mathrm{P} 21 \mathrm{a}$ of Hole $803 \mathrm{D}$. At both sites, the FO of $G$. angulisuturalis is associated with the upper part of Chron C11 Normal in agreement with Berggren et al. (1985) and Berggren and Miller (1988). Globigerina ciperoensis is also common throughout this zone in Hole $628 \mathrm{~A}$, but it is not present at all in this or subsequent zones in Hole 803D. Paragloborotalia opima is common throughout Subzone P21a of Hole 803D, but it occurs only rarely in Subzone P21a of Hole 628 A. P. opima is distinguished from P. nana based on the size criteria of Bolli and Saunders (1985).

The placement of the top of Subzone P21a is problematic at both sites because of the rare occurrence of Chiloguembelina cubensis throughout the upper Oligocene, particularly in Hole 628A. In Hole $628 \mathrm{~A}$, the top of Subzone P21a is based, in part (see below), on the last "common" (i.e., $>5 \%$ ) occurrence of $C$. cubensis (Fig. 5). Likewise in Hole $803 \mathrm{D}$, the top of Subzone P21a is tentatively placed at the last "common" occurrence of $C$. cubensis between Samples 130-803D- 

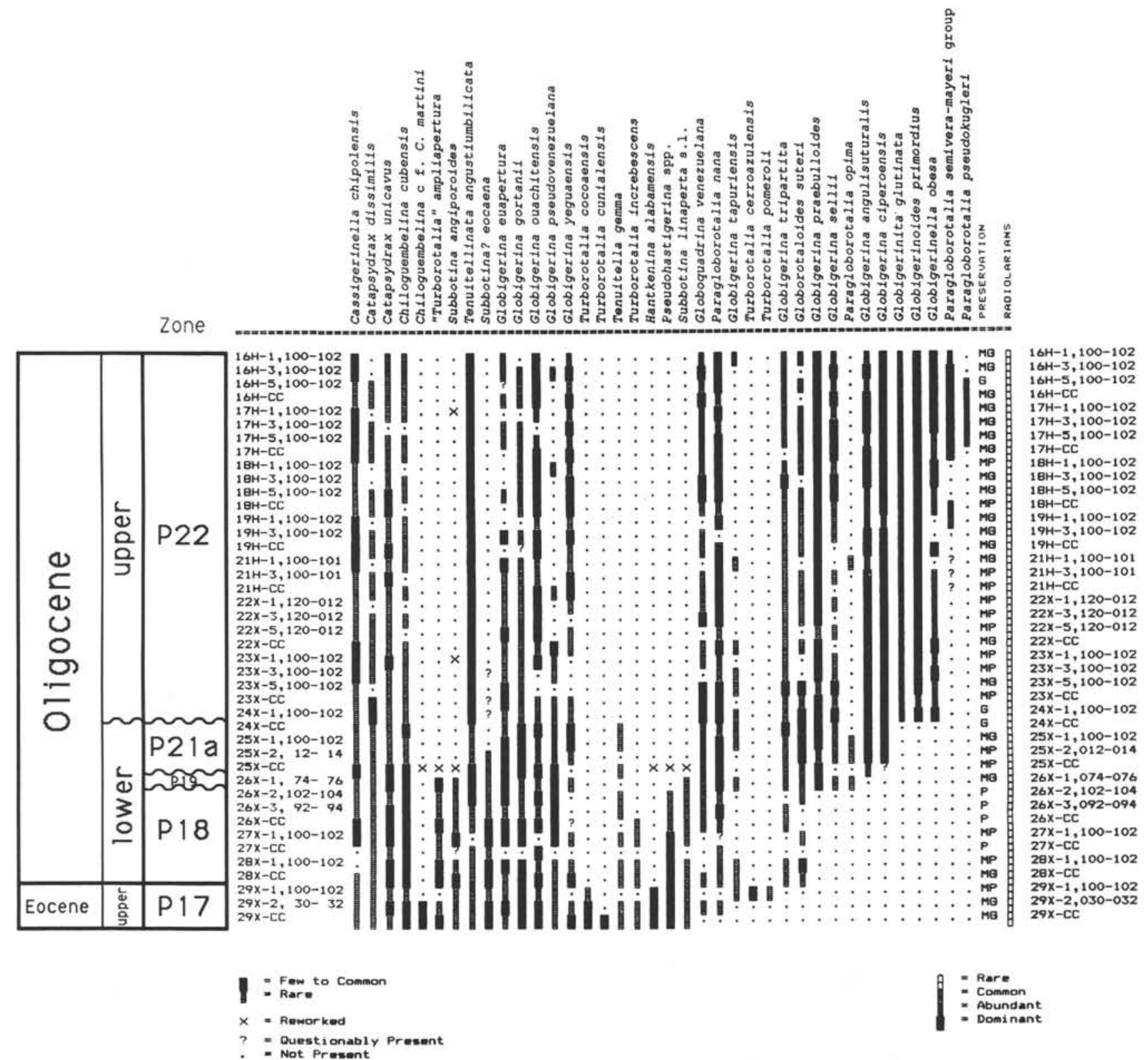

Figure 5. Graphic distribution of planktonic foraminifers throughout the uppermost Eocene and Oligocene of Hole 628A (Little Bahama Bank). Reworked species are denoted by an " $\mathrm{X}$ ". Foraminiferal relative abundance: rare $=<5 \%$ and few to common $=>5 \%$. Foraminiferal preservation: $\mathrm{G}=$ good, $\mathrm{MG}=$ moderately good, $\mathrm{MP}=$ moderately poor, and $\mathrm{P}=$ poor.

$46 \mathrm{X}-3,51-53 \mathrm{~cm}$ and $-47 \mathrm{X}-1,51-53 \mathrm{~cm}$ (Fig. 6). It should be noted, however, that Sample 130-803D-43X-1, 49-51 cm, near the top of Zone P21, contains "common" C. cubensis. Another sample, from the basal part of Zone 22, also contains common C. cubensis (Sample 130-803D-41X-1, 55-57 cm), but this latter sample also contains reworked uppermost Eocene or lower Oligocene specimens of Pseudohastigerina spp. and "Turborotalia" ampliapertura.

An unconformity separates Subzone P21a and Zone P22 in Hole $628 \mathrm{~A}$ based on the last common occurrence of $C$. cubensis in Sample 101-628A-24X-CC, and the FO of Globigerinoides primordius in Sample 101-628A-24X-1, 100-102 cm (Fig. 5). Core 101-628A-24X contains interbedded calcareous ooze and chalk, and unlithified and partially lithified packstone in the interval between these two samples (Austin, Schlager, Palmer, et al., 1986), suggesting erosion and/or downslope transport. This interval corresponds with two peaks in global hiatus distribution ( $\mathrm{PHb}$ and $\mathrm{PHaa}$ ), according to an analysis by Keller et al. (1987).
The basal sample of Subzone P21a in Hole 628A (Sample 101$628 \mathrm{~A}-25 \mathrm{X}-\mathrm{CC}$ ) contains numerous reworked taxa indicative of uppermost Eocene Zone P17, including Hantkenina alabamensis and Chiloguembelina sp., lending support to the interpretation of an unconformity between Zone P19 and Subzone P21a in Hole 628A.

\section{Globigerina angulisuturalis-Paragloborotalia opima Partial Range Subzone (Subzone P21b)}

Amended definition: Concurrent partial ranges of the nominate taxa between the last "common" occurrence of Chiloguembelina cubensis (base) and the LO of Paragloborotalia opima (top).

Discussion: Subzone P21b is not represented by the samples examined from Hole $628 \mathrm{~A}$ because of the presence of an unconformity between Subzone P21a and Zone P22. Paragloborotalia opima is a persistent taxon throughout Subzone P21b of Hole 803D, whereas Globigerina angulisuturalis occurs only sporadically (Fig. 6). Chi- 


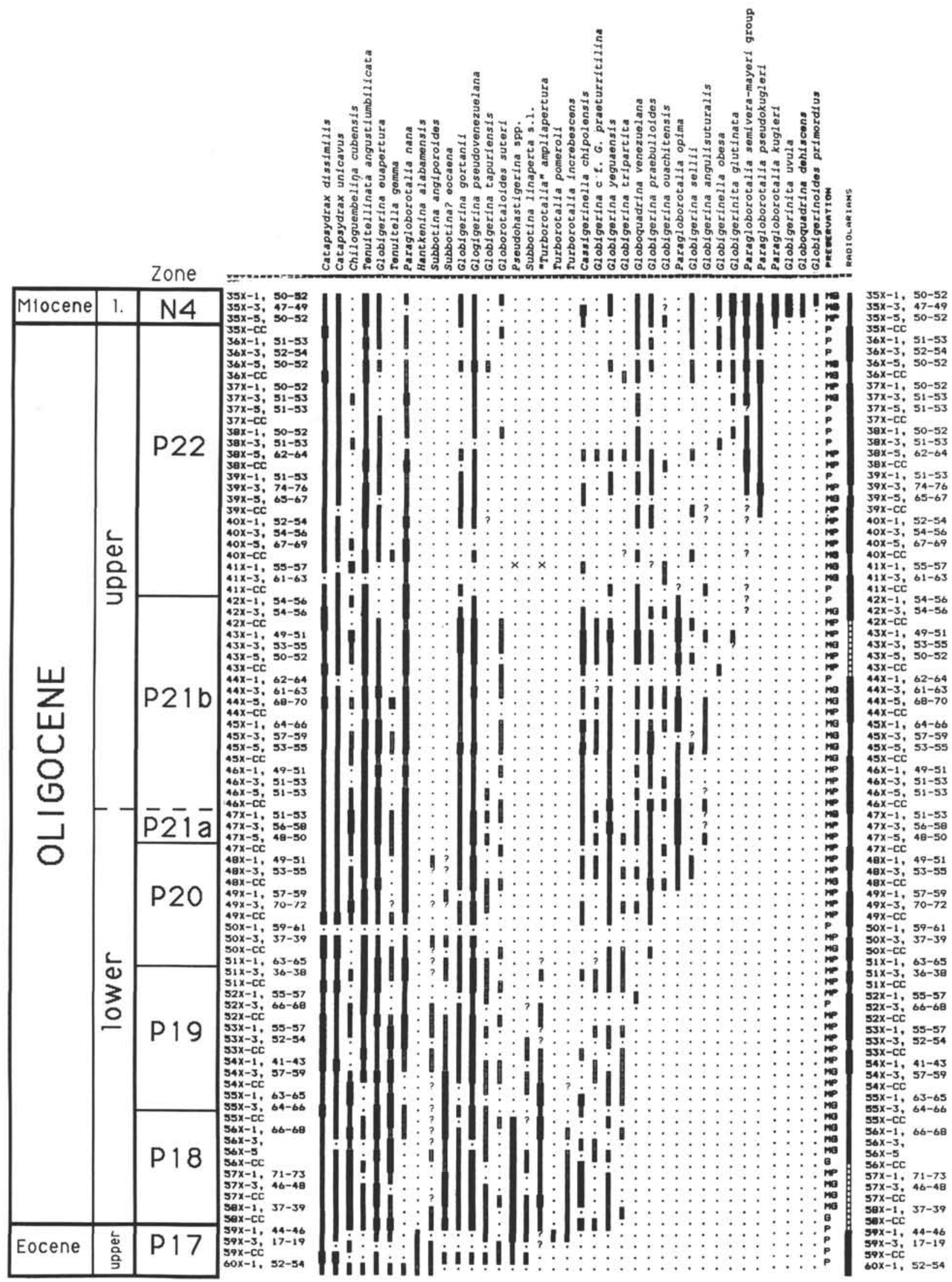

Figure 6. Graphic distribution of planktonic foraminifers throughout the uppermost Eocene to basal Miocene of Hole 803D (Ontong Java Plateau). Reworked species are denoted by an " $\mathrm{X}$ ". Foraminiferal relative abundance: rare $=<5 \%$ and few to common $=>5 \%$. Foraminiferal preservation: $\mathrm{G}=$ good, $\mathrm{MG}=$ moderately good, $\mathrm{MP}=$ moderately poor, $\mathrm{P}=$ poor. 
loguembelina cubensis also occurs sporadically throughout this zone in Hole 803D.

\section{Globigerina ciperoensis Partial Range Zone (Zone P22)}

Definition: Partial range of the nominate taxon between the LO of Paragloborotalia opima (base) and the FO of Paragloborotalia kugleri (top).

Discussion: Globigerinoides primordius occurs commonly throughout Zone P22 in Hole 628A. This taxon first occurs in Sample 101628A-24X-1, 100-102 cm (Fig. 5). Berggren et al. (1985) and Berggren and Miller (1988) reported the first occurrence of G. primordius at $25.8 \mathrm{Ma}$ (within Chron C7 Normal) and the first common occurrence of G. primordius at $24.5 \mathrm{Ma}$ (within Chron C6C Reversed). Although an unconformity is present at the base of Zone P22 in Hole 628A (between Samples 101-628A-24X-1, 100-102 cm, and -24XCC), the calcareous nannofossil data of Moran and Watkins (1988) indicate that the basal part of Zone P22 overlies the unconformity. This interpretation is based on the FO of Sphenolithus ciperoensis in Sample 101-628A-24X-1, 80-81 cm (just above the unconformity), and the LO of $S$. distentus in Sample 101-628A-23X-CC. These two calcareous nannofossil datums have ages of 30.2 and $28.2 \mathrm{Ma}$, respectively (Berggren et al., 1985). The Subzone P21b/Zone P22 boundary is placed at the LO of Paragloborotalia opima with an age of $28.2 \mathrm{Ma}$ (Berggren et al., 1985; Berggren and Miller, 1988). The FO of G. primordius, therefore, is closer to $28.0 \mathrm{Ma}$ (within Chron C8 Reversed), provided that specimens of $S$. distentus have not been reworked upward (Fig. 2). The FO of Paragloborotalia pseudokugleri (26.3 Ma) in Sample 101-628A-17 H-5, 100-102 cm, and the paleomagnetic record of the Zone P22 interval also support the conclusion of an "early" FO of G. primordius in Hole 628A (Fig. 2).

Globigerina ciperoensis does not occur in Hole 803D, but it is a common taxon throughout Zone P22 in Hole 628A. The FOs of Paragloborotalia semivera/mayeri and $P$. pseudokugleri are in the lower part of Zone P22 in Hole 803D. The FO of P. pseudokugleri is at the top of Chron C8 in Hole 803D (Fig. 3). In Hole 628A, the FO of $P$. pseudokugleri is associated with the middle part of Chron $\mathrm{C} 7$ Normal (Fig. 2).

Chiloguembelina cubensis occurs persistently throughout Zone P22 in Hole 628A, and sporadically through much of this zone in Hole 803D. Blow (1969, p. 222) had noted that $C$. cubensis can occur as high as Zone N3 (= P22). Paragloborotalia opima occurs from the upper part of Zone P20 through Subzones P21a and P21b in Hole $803 \mathrm{D}$, and its $\mathrm{LO}$ is a reliable datum at this site (Fig. 6). In contrast, P. opima occurs only sporadically in Hole $628 \mathrm{~A}$, and an anomalous occurrence of this taxon, based on the size criteria of Bolli and Saunders (1985), occurs in Zone P22 (Sample 101-628A-21H-1, $100-101 \mathrm{~cm}$ ) (Fig. 5). This particular sample correlates to the upper- most part of Chron C8 and contains no other evidence of reworking (Fig. 2). Several samples from Zone P22 in Hole 628A do contain reworked upper Eocene or lower Oligocene taxa, but the possibility exists that the $P$. opima/P. nana group represents ecophenotypes whose $P$. opima morphotype may display diachronous occurrences between the major ocean basins.

A major unconformity truncates the upper part of Zone P22 in Hole 628A. Keller et al. (1987) and Keller and Barron (1983) recognize numerous global hiatuses during the latest Oligocene to the middle Miocene ( $\mathrm{PHa}, \mathrm{NH} 1 \mathrm{a}, \mathrm{NH} 1 \mathrm{~b}, \mathrm{NH} 2$ ).

\section{Paragloborotalia kugleri Total Range Zone (Zone N4)}

Definition: Total range of the nominate taxon.

Discussion: Zone N4 is not present in Hole 628A because of the presence of a major unconformity between Zones P22 and N12 (Austin, Schlager, Palmer, et al., 1986). In Hole 803D, the FO of Paragloborotalia kugleri s.s. is in Sample 130-803D-35X-5, 50-52 $\mathrm{cm}$, the FO of Globoquadrina dehiscens is in Sample 130-803D-35X$3,47-49 \mathrm{~cm}$, and the FO of Globigerinoides primordius is in Sample 130-803D-35X-1, 50-52 cm (Fig. 6). Note the "late" FO of G. primordius in Hole 803D compared with its very early FO in Hole 628A. Berggren et al. (1985) noted that the FO of $G$. dehiscens is slightly higher than the FO of $P$. kugleri s.s. in the stratotype of the Aquitanian Stage. Our results from Hole 803D concur with that sequence of first occurrences.

\section{SEDIMENTATION RATES}

The planktonic foraminiferal datums, ages, and stratigraphic positions used to construct age vs. depth curves for Holes $803 \mathrm{D}$ and $628 \mathrm{~A}$ are presented in Tables 1 and 2, respectively. The ages of planktonic foraminiferal first (FO) and last occurrences (LO) are from Berggren et al. (1985). Hole 803D contains a continuous record of sediment accumulation during the Oligocene (Fig. 7). The average sedimentation rate is $17.0 \mathrm{~m} / \mathrm{m} . \mathrm{y}$. Upper Oligocene Zone P22 had a slightly lower rate of $13.8 \mathrm{~m} / \mathrm{m} . y$. compared with the lower and mid-Oligocene, which averaged $18.7 \mathrm{~m} / \mathrm{m}$.y.

The Oligocene of Hole 628A is punctuated by several hiatuses based on planktonic foraminiferal ranges. The evidence used to delineate these stratigraphic breaks was discussed in the previous section. Upper Oligocene Zone P22 had relatively high sedimentation rates; $31 \mathrm{~m} / \mathrm{m}$.y. represents a minimum rate because of the uncertainty of the magnitude of the unconformity between Zone P22 and Subzone P21a (Fig. 8). However, the calcareous nannofossil evidence of Moran and Watkins (1988) suggests that the basal part of Zone P22 is present above the unconformity (the nannofossil CP19a/CP19b zonal boundary, which correlates with the lowermost part of Zone P22

Table 1. Planktonic foraminifer datums, ages, and stratigraphic positions in Oligocene to basal Miocene, Hole 803D.

\begin{tabular}{|c|c|c|c|c|c|}
\hline $\begin{array}{l}\text { Planktonic foraminifer } \\
\text { datums }\end{array}$ & $\begin{array}{l}\text { Age } \\
\text { (Ma) }\end{array}$ & $\begin{array}{c}\text { Top of } \\
\text { interval }\end{array}$ & $\begin{array}{c}\text { Bottom of } \\
\text { interval }\end{array}$ & $\begin{array}{l}\text { Depth } \\
\text { (mbsf) }\end{array}$ & $\begin{array}{c}\text { Interpolated } \\
\text { depth } \\
\text { (mbsf) }\end{array}$ \\
\hline FO Paragloborotalia kugleri & 23.7 & $35 X-5,50-52$ & $35 \mathrm{X}-\mathrm{CC}$ & $319.50-322.01$ & 320.76 \\
\hline FO Paragloborotalia pseudokugleri & 26.3 & $39 \mathrm{X}-\mathrm{CC}$ & $40 X-1,52-54$ & $360.66-361.82$ & 361.24 \\
\hline LO Paragloborotalia opima & 28.2 & $42 X-1,54-56$ & $42 X-3,54-56$ & $381.24-384.78$ & 383.01 \\
\hline LO Chiloquembelina (common) & 30.0 & $46 \mathrm{X}-3,51-53$ & $46 \mathrm{X}-5,51-53$ & $422.81-425.81$ & 424.31 \\
\hline FO Globigerina angulisuturalis & 31.6 & $47 X-5,48-50$ & $47 \mathrm{X}-\mathrm{CC}$ & $435.48-436.20$ & 435.84 \\
\hline FO Paragloborotalia opima & 32.7 & $52 X-1,55-57$ & $52 X-3,66-68$ & $477.45-480.56$ & 479.01 \\
\hline LO "Turborotalia" ampliapertura & 32.8 & $52 X-3,66-68$ & $52 \mathrm{X}-\mathrm{CC}$ & $480.56-481.42$ & 480.99 \\
\hline LO Pseudohastigerina spp. & 34.0 & $54 \mathrm{X}-\mathrm{CC}$ & $55 X-1,63-65$ & $502.93-506.63$ & 504.78 \\
\hline LO Hantkenina spp. & 36.6 & $58 \mathrm{X}-\mathrm{CC}$ & $59 X-1,44-46$ & $535.86-544.74$ & 540.30 \\
\hline LO Turborotalia cerroazulensis gr. & 36.6 & $58 \mathrm{X}-\mathrm{CC}$ & $59 X-1,44-46$ & $535.86-544.74$ & 540.30 \\
\hline
\end{tabular}

Notes: $\mathrm{LO}=$ last occurrence and $\mathrm{FO}=$ first occurrence. Ages are from Berggren et al. (1985). 
Table 2. Planktonic foraminifer datums, ages, and stratigraphic positions in Oligocene, Hole 628A.

\begin{tabular}{|c|c|c|c|c|c|}
\hline $\begin{array}{l}\text { Planktonic foraminifer } \\
\text { datums }\end{array}$ & $\begin{array}{l}\text { Age } \\
\text { (Ma) }\end{array}$ & $\begin{array}{l}\text { Top of } \\
\text { interval }\end{array}$ & $\begin{array}{c}\text { Bottom of } \\
\text { interval }\end{array}$ & $\begin{array}{l}\text { Depth } \\
\text { (mbsf) }\end{array}$ & $\begin{array}{l}\text { Interpolated } \\
\text { depth (mbsf) }\end{array}$ \\
\hline FO Paragloborotalia pseudokugleri & 26.3 & $17 \mathrm{H}-5,100-102$ & $17 \mathrm{H}-\mathrm{CC}$ & $153.10-155.66$ & 154.38 \\
\hline LO Chiloguembelina (common) & 30.0 & $24 \mathrm{X}-1,100-102$ & $24 \mathrm{X}-\mathrm{CC}$ & $212.90-215.67$ & 214.28 \\
\hline FO Globigerina angulisuturalis & 31.6 & $25 \mathrm{X}-\mathrm{CC}$ & $26 \mathrm{X}-1,74-76$ & $225.21-232.14$ & 228.67 \\
\hline LO Subbotina angiporoides & 32.0 & $25 \mathrm{X}-\mathrm{CC}$ & $26 \mathrm{X}-1,74-76$ & $225.21-232.14$ & 228.67 \\
\hline LO "Turborotalia" ampliapertura & 32.8 & $25 \mathrm{X}-\mathrm{CC}$ & $26 \mathrm{X}-1.74-76$ & $225.21-232.14$ & 228.67 \\
\hline LO Pseudohastigerina spp. & 34.0 & $26 \mathrm{X}-1,74-76$ & $26 \mathrm{X}-2,102-104$ & $232.14-233.92$ & 233.03 \\
\hline LO Turborotalia cerroazulensis gr. & 36.6 & $28 \mathrm{X}-\mathrm{CC}$ & $29 \mathrm{X}-1,100-102$ & $254.39-261.20$ & 257.79 \\
\hline LO Hantkenina spp. & 36.6 & $28 \mathrm{X}-\mathrm{CC}$ & $29 \mathrm{X}-1,100-102$ & $254.39-261.20$ & 257.79 \\
\hline
\end{tabular}

Notes: $\mathrm{LO}=$ last occurrence and $\mathrm{FO}=$ first occurrence. Ages are from Berggren et al. (1985).

according to Berggren et al. [1985], occurs in Core 101-628A-23X and the unconformity occurs within Core 101-628A-24X). MidOligocene Subzone P21a is bounded by unconformities; it has a sedimentation rate of at least $9 \mathrm{~m} / \mathrm{m}$.y. Lower Oligocene Zone P19 is also bounded by unconformities and is represented by only one sample (101-628A-26X-1, 74-76 cm). Cores 101-628A-24X to - $26 \mathrm{X}$ contain numerous beds of unlithified packstone and floatstone, and it is within this interval that the three Oligocene unconformities occur. Cores 101-628A-27X and -28X consist of calcareous ooze and chalk with no evidence of redeposition or unconformities. This interval had an average sedimentation rate of $9.5 \mathrm{~m} / \mathrm{m}$.y. and represents lower Oligocene Zone P18.

\section{COMPARISON OF LOW-LATITUDE SITES 628 AND 803}

Overall, the total diversity and composition of planktonic foraminiferal assemblages through the Oligocene of Holes 628 A (Little Bahama Bank) and 803D (Ontong Java Plateau) are very similar. In addition, the observed stratigraphic ranges of many of the taxa are similar at both sites (Fig. 9). Important differences are present, however, some of which are paleoceanographically related whereas others may be caused by dissolution at the Pacific site.

In the lower Oligocene (Zone P18 to Subzone P21a), both holes contain common occurrences of Catapsydrax dissimilis, $C$. unicavus, Chiloguembelina cubensis, Pseudohastigerina spp., Tenuitella gemma, "Turborotalia" ampliapertura, Subbotina? eocaena, G. euapertura, G. gortanii, and G. pseudovenezuelana (Figs. 5 and 6). Other taxa characteristic of the lower Oligocene of both sites but with less persistent and rare occurrences include Paragloborotalia nana, Tenuitellinata angustiumbilicata, Turborotalia increbescens, Globigerina tapuriensis, G. tripartita, Subbotina linaperta s.l., S.? yeguaensis, and Globorotaloides suteri. Subbotina angiporoides, Globigerina angulisuturalis, G. ouachitaensis, and $G$. praebulloides occur at both sites but are significantly more common in Hole 628A, whereas Paragloborotalia opima is much more common in Hole 803D. The poor showing of the three species of Globigerina in Hole 803D may be a result of enhanced dissolution at this site, but the distribution and abundance differences of $S$. angiporoides and $P$. opima between Holes $628 \mathrm{~A}$ and $803 \mathrm{D}$ are probably related to paleoceanographic differences between the subtropical western North Atlantic and tropical western Pacific during early Oligocene time.

In the upper Oligocene (Subzone P21b to Zone P22), both holes contain common occurrences of Catapsydrax spp., Paragloborotalia nana, Globigerina angustiumbilicata, G. venezuelana, Paragloborotalia pseudokugleri, and $P$. semivera/mayeri. Other taxa with persistent but rare occurrences at both sites include Globigerinita glutinata, Globigerina euapertura, and Chiloguembelina cubensis. Globigerinella obesa, Globigerina angulisuturalis, G. ouachitaensis, G. praebulloides, G. sellii, and Subbotina? yeguaensis are present in the upper Oligocene of both sites but are much more common in Hole 628 A. Globigerina tripartita virtually vanishes from the upper Oligocene assemblages of Hole 803D, but it is a persistent taxon through- out Zone P22 in Hole 628A. In addition, Globigerinoides primordius and Globigerina ciperoensis are common taxa of the upper Oligocene (Zone P22) of Hole 628A but are not present in upper Oligocene sediments of Hole 803D. Enhanced dissolution, particularly in Zone P22 of Hole 803D, may be primarily responsible for the differences in upper Oligocene assemblages between the two sites. However, the marked differences in the distribution of Globigerinoides primordius, which first occurs in basal Miocene Zone N4 of Hole 803D but ranges throughout uppermost Oligocene Zone P22 of Hole 628A, may be related to paleoceanographic differences between the two sites.

\section{COMPARISON WITH THE SUBANTARCTIC}

Recent studies of planktonic foraminifers from subantarctic Oligocene deep-sea sequences have been published by Stott and Kennett (1990) from the Maud Rise in the Weddell Sea, Huber (1991) from the southern Kerguelen Plateau, and Nocchi et al. (1991) from the South Atlantic (Fig. 1). Important differences in species distribution and assemblage composition exist between the low and southern high latitudes that bear on the paleobiogeography and paleoceanography of the Oligocene.

Characteristic taxa of the subantarctic lower Oligocene assemblages include Subbotina angiporoides, S. utilisindex, Globorotaloides suteri, Chiloguembelina cubensis, Tenuitella gemma, T. munda, Praetenuitella spp., Paragloborotalia nana, Catapsydrax unicavus, and Globigerina labiacrassata. Globigerina labiacrassata, Tenuitella munda, and Praetenuitella spp. were not found in lower Oligocene sediments in either of the low latitude sites. Subbotina angiporoides and S. utilisindex (probably equivalent to our $S$. linaperta s.1.) occur in much greater abundances in the subantarctic than in the low latitudes. The other taxa occur in similar abundances in both the low and southern high latitudes. Pseudohastigerina spp., Turborotalia increbescens, "Turborotalia" ampliapertura, Subbotina? eocaena, S.? yeguaensis, Globigerina gortanii, G. tapuriensis, G. tripartita, and G. pseudovenezuelana are noticeably absent or have rare occurrences in the subantarctic lower Oligocene assemblages. Huber (1991) reports rare but persistent occurrences of Pseudohastigerina micra, Subbotina? eocaena, Globigerina gortanii, and $G$. pseudovenezuelana from one of two holes examined from the southern Kerguelen Plateau.

Subantarctic assemblages from the upper Oligocene are characterized by Catapsydrax spp., Globigerina labiacrassata, G. euapertura, G. praebulloides, Globigerinita juvenilis, Globorotaloides suteri, Tenuitella munda, and Tenuitellinata angustiumbilicata. Paragloborotalia opima, Globigerina ciperoensis, and Globigerinella obesa are also noted in the South Atlantic holes (Nocchi et al., 1991). Globigerina labiacrassata was not observed in upper Oligocene sediments from either of the low-latitude sites, and Tenuitella munda occurs only sporadically in Hole 803D. Globigerina euapertura and Globigerinita juvenilis (equivalent to our G. glutinata) are more common in the upper Oligocene assemblages from the subantarctic. The other taxa occur in similar abundances in both the low and southern high latitudes. Noticeably absent, or with rare occurrences 


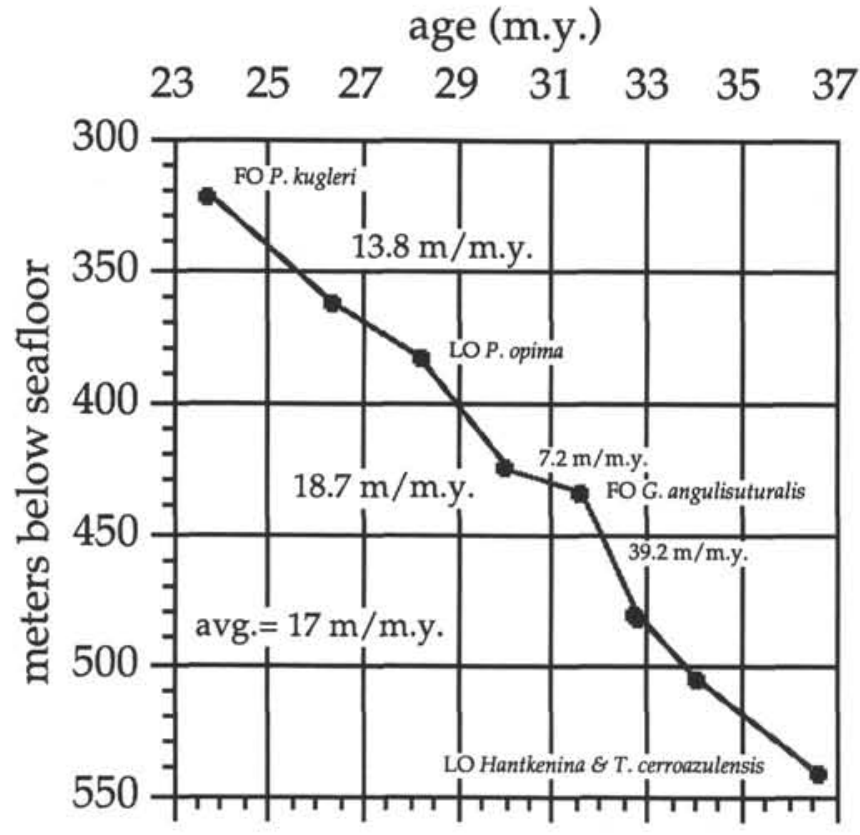

Figure 7. Age vs. depth plot of the Oligocene to basal Miocene of Hole 803D based on planktonic foraminiferal datums presented in Table 1. The low sedimentation rates in the mid-Oligocene may, in part, be an artifact of a "low" LO for "common" Chiloguembelina spp. at this site.

in the subantarctic upper Oligocene assemblages are Paragloborotalia pseudokugleri, P. semivera/mayeri, Globigerina angulisuturalis, G. gortanii, G. ouachitaensis, G. sellii, G. tripartita, and Subbotina? yeguaensis.

\section{SUMMARY AND CONCLUSIONS}

Hole 803D from the tropical western Pacific (Ontong Java Plateau, $4.5^{\circ} \mathrm{S}$ paleolatitude) contains a complete uppermost Eocene to basal Miocene sequence based on planktonic foraminiferal evidence. Hole 628A from the subtropical western North Atlantic (Little Bahama Bank, $25.8^{\circ} \mathrm{N}$ paleolatitude) is possibly complete across the Eocene/ Oligocene boundary, but it contains three unconformities within the Oligocene: between Zones P18/P19, P19/P21a, and P21a/P22. The uppermost part of Zone P22 is truncated by an unconformity and is overlain by sediments of Zone N12 (middle Miocene).

Chiloguembelina cubensis has been found to range persistently throughout upper Oligocene Subzone P21b and in much of Zone P22 in Holes 628A and 803D. In Hole 803D, the LO of C. cubensis is at the top of Chron C7 or basal C6C (25.3-25.5 Ma, according to Berggren et al., 1985). Berggren et al. (1985) and Berggren and Miller (1988) use the LO of C. cubensis to define the top of Subzone P21a at $30.0 \mathrm{Ma}$ (within Chron $\mathrm{C} 10 \mathrm{Normal}$ ). We propose the use of the last "common" ( $>5 \%)$ occurrence of $C$. cubensis to define the Subzone $\mathrm{P} 21 \mathrm{a} / \mathrm{P} 21 \mathrm{~b}$ boundary.

In Hole $628 \mathrm{~A}$, common ( $>5 \%)$ Globigerinoides primordius is found to range throughout uppermost Oligocene Zone P22. Although Zone $\mathrm{P} 22$ is bounded at its base by an unconformity (between Samples 101-628A-24X-1, 100-102 cm, and -24X-CC), the calcareous nannofossil data of Moran and Watkins (1988) indicate that little or none of the basal Zone P22 is missing (the nannofossil Zone NP24/NP25 boundary occurs within Core 101-628A-23X). This places the FO of G. primordius within Chron C8 Reversed (27.7-28.1 Ma, according to Berggren et al., 1985). This FO is significantly older than the first "rare" G. primordius at $25.8 \mathrm{Ma}$ and the first "common" G. primordius at 24.5 Ma cited by Berggren et al. (1985) and Berggren and Miller (1988).

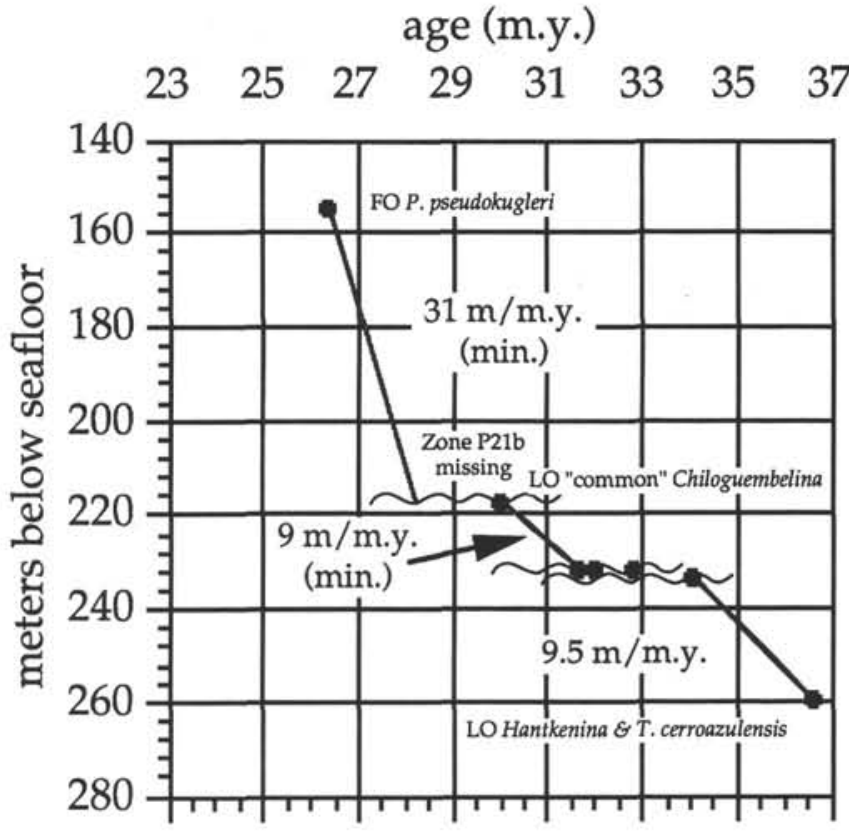

Figure 8. Age vs. depth plot of the Oligocene of Hole 628A based on planktonic foraminiferal datums presented in Table 2 . Wavy lines correspond with hiatuses in the section.

The FO of Paragloborotalia pseudokugleri appears to be diachronous between Holes 628A and 803D. In Hole 628A, the FO of $P$. pseudokugleri is within Chron C7 Normal (approximately $25.8 \mathrm{Ma}$, according to Berggren et al., 1985). In Hole 803D, the FO of P. pseudokugleri is at the top of Chron C8 (approximately $27.0 \mathrm{Ma}$, according to Berggren et al., 1985).

The FO of Globigerina angulisuturalis, used to define the Zone P20/Subzone P21a boundary, is found within Chron C11 Normal in Holes 628A and 803D (31.6 Ma, according to Berggren et al., 1985). These findings are consistent with Berggren et al. (1985) and Berggren and Miller (1988), suggesting that $G$. angulisuturalis has an isochronous FO in the Atlantic and Pacific. However, Hess et al. (1989) document a diachronous FO for this taxon between ocean basins based on the Sr-isotope stratigraphy. The fact that an unconformity is present at the base of Subzone P21a in Hole 628A (North Atlantic) complicates the interpretation somewhat, but the data of Hess et al. (1989) suggest that the FO of G. angulisuturalis is younger in the Atlantic (29.8-31.2 Ma) than in the Pacific (31.8-32.0 Ma) for the sites investigated, a finding that contrasts with the results from Hole 628A (i.e., the FO of G. angulisuturalis is at least $31.6 \mathrm{Ma}$ in the Bahamas site).

In general, taxon ranges, total diversity, and the composition of the planktonic foraminiferal assemblages from Holes 628A and 803D are similar. Some differences exist between the sites in assemblage composition, particularly in the species abundances Globigerina, but these differences may be more closely related to enhanced dissolution at the Pacific site than to major differences in the physical or biological oceanography of the water masses between the sites during the Oligocene. Clear exceptions to this trend include the greater abundance of Subbotina angiporoides in subtropical Hole 628A and the greater abundance of Paragloborotalia opima in tropical Hole 803D.

A comparison between the low and southern high latitudes (Stott and Kennett, 1990; Huber, 1991; Nocchi et al., 1991) illustrates some similarities in the composition of Oligocene planktonic foraminiferal assemblages, as well as some important differences. The relative abundances of such taxa as Catapsydrax spp., Tenuitella gemma, Paragloborotalia nana, Globigerina angustiumbilicata, G. praebulloides, and Globorotaloides suteri are similar in the subantarctic and 

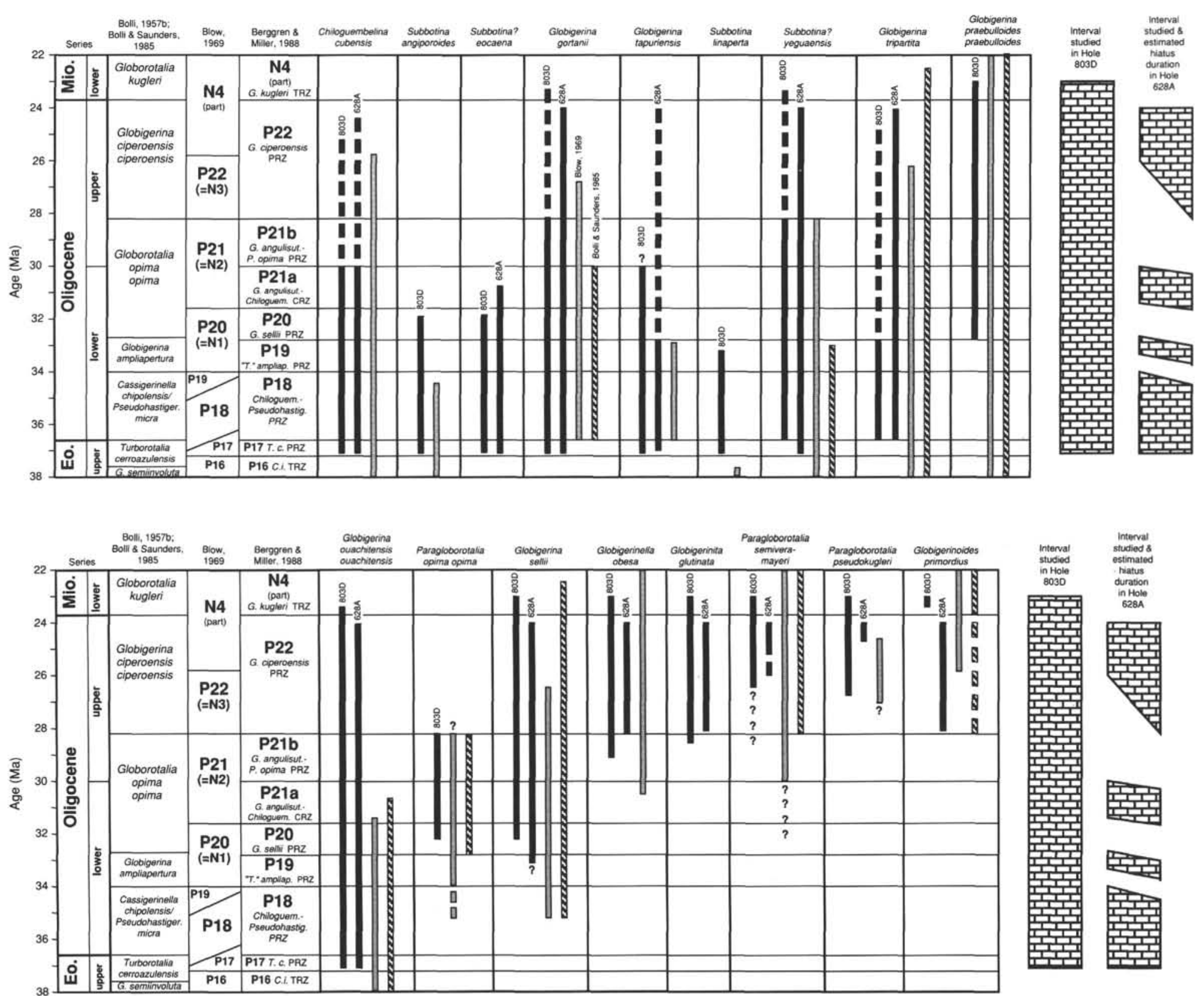

Figure 9. Comparison of selected planktonic foraminiferal stratigraphic ranges in Holes 628A and 803D. The ranges are compared with the published ranges of Blow (1969; stippled bars) and Bolli and Saunders (1985; diagonal striped bars). Also shown is the approximate extent of the stratigraphic records studied in both sites, and the approximate duration of hiatuses based on the planktonic foraminiferal evidence from the Oligocene of Hole 628A. 
low latitudes. Subbotina angiporoides, S. utilisindex, Globigerina euapertura, Tenuitella munda, and Globigerinita juvenilis are more common in the subantarctic than in the tropics/subtropics. Globigerina labiacrassata, G. brazeri, G. woodi, Catapsydrax echinatus, and species of Praetenuitella were not recorded in either low-latitude site examined here. Noticeably absent, or with rare occurrences in the subantarctic Oligocene assemblages, are Pseudohastigerina spp., Turborotalia increbescens, "Turborotalia" ampliapertura, Paragloborotalia opima, P. pseudokugleri, P. semivera/mayeri, Globigerinella obesa, Subbotina? eocaena, S.? yeguaensis, Globigerina angulisuturalis, G. gortanii, G. ouachitaensis, G. sellii, G. tapuriensis, G. tripartita, and $G$. pseudovenezuelana. This comparison of planktonic foraminiferal assemblages between the low and southern high latitudes illustrates that biogeographic gradients, although not as pronounced as during the late Neogene, were nonetheless significant during the Oligocene.

\section{ACKNOWLEDGMENTS}

R.M.L. would like to thank the crew, marine technicians, and fellow scientific staff of Leg 130 for an enjoyable, interesting, and productive experience. We would like to thank Bill Berggren for discussions at the microscope concerning Oligocene taxonomy, and biostratigraphy and magnetostratigraphy in general. We would also like to acknowledge discussions with Marie-Pierre Aubry. The paper benefited from reviews by William A. Berggren, Brian T. Huber, and Richard K. Olsson. This research was supported by a USSAC grant for post-cruise research. Scanning electron micrographs were taken at the University of Massachusetts Microscopy Facility. Thanks to Ed Basgall and Lucy Yin for assistance.

\section{TAXONOMIC NOTES}

We have attempted to document as many taxa as possible within the time constraints of this study, but we have not separated out all species, particularly those of the genus Globigerina. Unidentified globigerinids occur in all samples examined and therefore have not been included on the distribution tables. We did, however, focus much of our effort on the species concepts and stratigraphic ranges of the commonly known lowlatitude taxa, with particular attention addressed to the range of morphologic variability and the criteria used to distinguish closely related taxa. Generic assignments based on phylogenetic relationships for some Oligocene taxa have yet to be firmly established. Because this is primarily a biostratigraphic study, we largely followed the recent literature in assigning individual species to genera. The following is a list of the principal references used to identify species: Blow and Banner (1962), Blow (1969), Bolli (1957a, 1957b), Bolli and Saunders (1985), Jenkins (1985), Kennett and Srinivasan (1983), Poore and Brabb (1977), Poore and Bybell (1988), Stainforth et al. (1975), and Toumarkine and Luterbacher (1985).

\section{Cassigerinella chipolensis (Cushman and Ponton)} Plate 7, Figs. $18-19$

Cassidulina chipolensis Cushman and Ponton, 1932, p. 98, pl. 15, figs. 2a-c.

Discussion: Cassigerinella chipolensis differs from Cassigerinella sp. by its slightly smaller size and more inflated chambers.

\section{Cassigerinella sp. \\ Plate 7, Fig. 17}

Discussion: Cassigerinella sp. is distinguished from $C$. chipolensis by its slightly larger size and distinctly flattened, lenticular test. This taxon was only recorded in the lower to mid-Oligocene of Hole 628A.

Catapsydrax dissimilis (Cushman and Bermudez) Plate 3, Figs. 16-17
Globigerina dissimilis Cushman and Bermudez, 1937, p. 25, pl. 3, figs. 4-6. Catapsydrax unicavus Bolli, Loeblich and Tappan Plate 3, Fig. 15

Catapsydrax unicavus Bolli, Loeblich and Tappan, 1957, p. 37, pl. 7, figs 9a-c.

Discussion: The bulla of Catapsydrax unicavus is low across the umbilicus in contrast with the inflated bulla-like final chamberlet often observed in Globigerina gortanii. Catapsydrax unicavus is distinguished from Globorotaloides suteri in having only four chambers in the final whorl, an umbilical aperture, and a bulla centered over the umbilicus.

\section{Chiloguembelina cubensis (Palmer)}

Plate 1, Figs. 14-17

Guembelina cubensis Palmer, 1934, p. 73, text-figs. 1-6.

Discussion: Chiloguembelina cubensis ranges throughout the uppermost Eocene and Oligocene of Holes 628A and 803D, although it becomes rare in the upper Oligocene (Subzone P21b to Zone P22).

\section{Chiloguembelina cf. C. martini (Pijpers) \\ Plate 1, Fig. 13}

Chiloguembelina martini Pijpers, 1933, p. 57, figs. 6-10.

Discussion: Chiloguembelina cf. C. martini is distinguished from $C$. cubensis by its larger size, flatter test, and droopy chambers. This taxon is restricted to the uppermost Eocene of Hole 628A.

\section{Globigerina angulisuturalis Bolli \\ Plate 9, Figs. 1-6}

Globigerina ciperoensis angulisuturalis Bolli, 1957b, p. 109, pl. 22, figs. 11a-c; Bolli and Saunders, 1985, pp. 182-183, figs. 13.4-7.

Discussion: This distinctive taxon is closely related to Globigerina ciperoensis, but it is distinguished by its deep U-shaped intercameral sutures and generally smaller size. G. angulisuturalis is a common taxon of the mid- and upper Oligocene of Hole 628A, but it is recorded only sporadically in Hole 803D.

\section{Globigerina ciperoensis Bolli} Plate 9, Figs. 7-10

Globigerina ciperoensis ciperoensis Bolli, 1957b, p. 109, pl. 22, figs. 10a-b; Bolli and Saunders, 1985, pp. 182-183, figs. 13.1-3.

Discussion: Globigerina ciperoensis is a common taxon of the mid- and upper Oligocene of Hole 628A, but it was not observed in Hole 803D.

\section{Globigerina euapertura Jenkins}

Plate 4, Figs. 10-13

Globigerina euapertura Jenkins, 1960, p. 351, pl. 1, figs. 8a-c.

Discussion: Globigerina euapertura is characterized by its relatively large size, four chambers in the final whorl, and a broad, low aperture that lacks a lip. It is distinguished from Subbotina? eocaena s.l. by having a distinctly broader and lower arched aperture and a more compact test (i.e., more embracing chambers), G. euapertura differs from Globigerina pseudovenezuelana in having an arched aperture, as opposed to the lower, nearly straight aperture of the latter taxon. A gradational specimen is illustrated on Plate 4, Figure 14. It differs from "Turborotalia" ampliapertura in having a broader and lower arched aperture. G. euapertura ranges through the uppermost Eocene and Oligocene of Holes 628A and 803D.

\section{Globigerina gortanii (Borsetti) Plate 3, Figs. 7-14}

Catapsydrax gortanii Borsetti, 1959, p. 205, pl. 1, figs. 1a-d. Globigerina gortanii (Borsetti) Bolli and Saunders, 1985, p. 177, fig. 13.17.

Discussion: Globigerina gortanii is characterized by its bulla-like final chamberlet and variable dorsal convexity. The last chamberlet in G. gortanii is "parachute-like" in its inflation, thereby distinguishing it from the true bulla in 
Catapsydrax unicavus. High-spired forms may be referred to as Globigerina praeturritilina Blow and Banner (e.g., Plate 3, Fig. 9). Without the bulla-like chamberlet, G. gortanii resembles Subbotina? eocaena in overall chamber shape and arrangement. G. gortanii was found throughout the uppermost Eocene-basal Miocene interval studied.

\section{Globigerina ouachitaensis Howe and Wallace}

Plate 9, Figs, 11-12

Globigerina ouachitaensis Howe and Wallace, 1932, p. 74, pl. 10, figs. 7a-c.

Discussion: Globigerina ouachitaensis is characterized by its relatively wide umbilicus, four globular chambers in the final whorl, and moderate dorsal convexity. It is distinguished from Globigerina ciperoensis in possessing one less chamber in its final whorl and a generally higher spire.

\section{Globigerina praebulloides Blow}

Plate 9, Figs. 13-14

Globigerina praebulloides Blow, 1959, p. 180, pl. 8, figs. 47a-c.

Discussion: Globigerina praebulloides is characterized by its relatively large final chamber, distinctive elongate shape, and lobate outline. G. praebulloides lacks the apertural lip or well-developed imperforate rim found in G. ouachitaensis and Subbotina? eocaena. In addition, G. praebulloides tends to be smaller than the latter taxon.

\section{Globigerina pseudovenezuelana Blow and Banner} Plate 4, Figs. 15-17

Globigerina pseudovenezuelana Blow and Banner, 1962, p. 100, pl. 11, figs. J-L; Poore and Brabb, 1977, p. 256, pl. 4, figs. 8-9; Bolli and Saunders, 1985 , pp. 180-181, fig. 13.21.

Discussion: Globigerina pseudovenezuelana is distinguished from G. euapertura by having a narrower umbilicus and lower, nearly straight aperture. A gradational specimen is illustrated on Plate 4, Figure 14. G. pseudovenezuelana tends to be slightly smaller and has more inflated chambers than Globoquadrina venezuelana.

\section{Globigerina tapuriensis Blow and Banner}

$$
\text { Plate 5, Figs. 11-16 }
$$

Globigerina tripartita tapuriensis Blow and Banner, 1962, p. 97, pl. 10, figs. H-K. Globigerina tapuriensis (Blow and Banner) Bolli and Saunders, 1985, p. 181, fig. 14.12 .

Discussion: Globigerina tapuriensis differs from Globigerina euapertura in having only three chambers in the final whorl that increase rapidly in size. The aperture of $G$. tapuriensis is centered over a suture rather than over a chamber as in G. euapertura. It differs from Globigerina tripartita in having more globular, inflated chambers, particularly the ultimate chamber, and in having an arched aperture. The overall chamber arrangement and chamber shape of $G$. tapuriensis is similar to Globigerina sellii, but it differs from the latter taxon in lacking a flattened apertural face.

\section{Globigerina tripartita Koch} Plate 5, Figs. 6-10

Globigerina bulloides var. tripartita Koch, 1926, p. 746, figs. 21a-b. Globigerina tripartita (Koch) Bolli and Saunders, 1985, p. 181, fig. 14.13.

Discussion: Globigerina tripartita is characterized by its compact test, three chambers in the final whorl, and appressed, caplike final chamber. The final chamber is often smaller and/or less inflated than the penultimate chamber. Like $G$. sellii and $G$. tapuriensis, $G$. tripartita has its aperture centered over a suture. G. tripartita differs from $G$. tapuriensis in having a distinctive appressed final chamber and narrower umbilicus. This taxon displays considerable morphologic variability.

$$
\begin{aligned}
& \text { Globigerinella obesa (Bolli) } \\
& \text { Plate 7, Figs. 15-16 }
\end{aligned}
$$

Globorotalia obesa Bolli, 1957b, p. 119, pl. 29, figs. 2a-3.
Globigerinella obesa (Bolli) Kennett and Srinivasan, 1983, p. 234, pl. 59, figs. 2-5.

Discussion: Globigerinella obesa resembles Tenuitella munda in chamber number and arrangement, but the former taxon is larger and has larger pores.

\section{Globigerinita glutinata s.l. Parker} Plate 6, Fig. 1

Globigerinita glutinata Parker, 1962, p. 246, pl. 9, figs. 1-16.

Discussion: We did not distinguish Tenuitellinata juvenilis (Egger) and Globigerinita glutinata as two separate taxa, following Kennett and Srinivasan (1983). Li Qianyu (1987, p. 311) states that $T$. juvenilis first appears in the early Oligocene and $G$. glutinata s.s. first appears in the early Miocene. Although we acknowledge that nonbullate forms (i.e., "juvenilis") are more common in the Oligocene than bullate forms (i.e., "glutinata"), we find occasional bullate forms in the upper Oligocene of Holes 628A and 803D.

\section{Globigerinoides primordius Blow and Banner} Plate 9, Figs. 15-20

Globigerinoides quadrilobatus primordius Blow and Banner, 1962, p. 115, pl. 9, figs. Dd-Ff.

Discussion: Well-developed specimens of Globigerinoides primordius are present in the basal part of Zone P22 in Hole 628A (Plate 9, Figs. 17-18). G. primordius is a common taxon throughout upper Oligocene Zone P22 in Hole 628A. In Hole 803D, the FO of G. primordius is in the basal Miocene Zone N4.

$$
\begin{gathered}
\text { Globoquadrina dehiscens (Chapman, Parr and Collins) } \\
\text { Plate 8, Figs. 17-18 }
\end{gathered}
$$

Globorotalia dehiscens Chapman, Parr, and Collins, 1934, p. 569, pl. 11, fig. 6.

$$
\text { Globorotaloides suteri Bolli }
$$$$
\text { Plate 3, Fig. } 18
$$

Globorotaloides suteri Bolli, 1957b, p. 117, pl. 27, figs. 13a-c.

Discussion: Globorotaloides suteri is distinguished from Catapsydrax unicavus in having four to five chambers in the final whorl and an umbilicalextraumbilical aperture. G. suteri often possesses a bulla-like final chamber that is variable in size, but when present it typically is not centered over the umbilicus as in $C$. unicavus (i.e., it resembles a kuemmerform final chamber).

\section{Hantkenina alabamensis Cushman} Plate 1, Figs. 11-12

Hantkenina alabamensis Cushman, 1925, p. 3, pl. 1, fig. 1.

$$
\text { Paragloborotalia kugleri (Bolli) }
$$

Plate 8, Figs. 1-5

Globorotalia kugleri Bolli, 1957b, p. 118, pl. 28, figs. 5a-c.

Paragloborotalia kugleri (Bolli) Spezzaferri, 1991, p. 317, pl. 1, figs. 5a-c, pl. 2, figs. 1a-d and $2 a-d$.

Discussion: Paragloborotalia kugleri is assigned to the genus Paragloborotalia following the work of Spezzaferri (1991). Sensu stricto forms of $P$. kugleri are used to define the base of the Miocene in the low latitudes (Berggren et al., 1985; Berggren and Miller, 1988). P. kugleri is distinguished from $P$. pseudokugleri by its subacute margin and arched sutures on the spiral side.

\section{Paragloborotalia nana (Bolli) \\ Plate 7, Figs. 1-2}

Globorotalia opima nana Bolli, 1957b, p. 118, pl. 28, figs. 3a-c.

Discussion: Paragloborotalia nana is distinguished from $P$. semivera/mayeri by its slightly smaller size, fewer chambers, and lower apertural arch. $P$. nana is distinguished from $P$. opima by its smaller size following the size criteria of Bolli and Saunders (1985). 
Paragloborotalia opima (Bolli)

Plate 7, Figs. 3-4 and 9

Globorotalia opima opima Bolli, 1957b, p. 117, pl. 28, figs. la-c.

Discussion: Bolli and Saunders (1985) established size criteria to distinguish Paragloborotalia opima from P. nana. According to these criteria, $P$. opima must be $>0.38 \mathrm{~mm}$ (most fall in a range from 0.39 to $0.50 \mathrm{~mm}$ ). $P$. opima is common and well developed in the mid-Oligocene of Hole 803D, but it occurs only sporadically in Hole 628A.

Paragloborotalia pseudokugleri (Blow)

Plate 8, Figs. 8-16

Globorotalia (Turborotalia) pseudokugleri Blow, 1969, p. 391, pl. 10, figs. $4-6$, pl. 39, figs. $5-6$.

Paragloborotalia pseudokugleri (Blow) Spezzaferri, 1991, p. 315, pl. 1, figs. $1 \mathrm{a}-\mathrm{c}, 2 \mathrm{a}-\mathrm{d}$, and $3 \mathrm{a}-\mathrm{d}$.

Discussion: Paragloborotalia pseudokugleri is assigned to the genus Paragloborotalia following the work of Spezzaferri (1991). P. pseudokugleri is distinguished from $P$. kugleri by its rounded margin and straight sutures on the spiral side. In the early part of its range, P. pseudokugleri is distinguished from juvenile specimens of the $P$. semivera/mayeri group by possessing 6 chambers in the final whorl compared with 5 to $5-1 / 2$ in the latter. P. pseudokugleri is distinctly circular in outline and generally possesses a lower apertural arch compared with $P$. semivera/mayeri.

\section{Paragloborotalia semivera/mayeri group} Plate 7, Figs. 5-8 and $10-14$

Globorotalia mayeri Cushman and Ellisor, 1939, p. 11, pl. 2, figs. 4a-c. Globigerina semivera Hornibrook, 1961, p. 149, pl. 23, figs. 455-457.

Discussion: We did not attempt to distinguish between Paragloborotalia semivera and $P$. mayeri because of their very close similarity in upper Oligocene sediments. The $P$. semivera/mayeri group differs from $P$. nana in their slightly larger size, more numerous chambers (5 to 5-1/2 compared with 4 ), distinctive oblong shape, and more open umbilicus. $P$. semivera/mayeri is distinguished from $P$. opima by its smaller size and less inflated chambers.

\section{Pseudohastigerina micra (Cole) \\ Plate 6, Figs. 14-17 and 20-21}

Nonion micrus Cole, 1927, p. 22, pl. 5, fig. 12.

Pseudohastigerina micra (Cole) Toumarkine and Luterbacher, 1985, pp. 118-119, figs. 21.1-8.

Discussion: Pseudohastigerina micra was difficult to distinguish from $P$. cf. naguewichiensis because of the small size of the species and the nature of preservation in many of the uppermost Eocene-lower Oligocene samples (e.g., note etching on specimens illustrated on Plate 6, Figs. 20-21, giving the impression of "larger" pores). In general, $P$. micra has more chambers, a smoother wall, and a subacute margin as compared with $P$. naguewichiensis. However, at the stereomicroscope the two taxa display many gradational features.

\section{Pseudohastigerina cf. naguewichiensis (Myatliuk) Plate 6, Figs. 18-19}

Globigerinella naguewichiensis Myatliuk, 1950, p. 281, pl. 4, figs. 4a-b. Pseudohastigerina naguewichiensis (Myuatliuk) Toumarkine and Luterbacher, 1985, p. 119, figs. 21.10-16.

Discussion: Pseudohastigerina $\mathrm{cf}$. $P$. naguewichiensis is distinguished from $P$. micra by its rounded margin and more coarsely perforate test.

Subbotina angiporoides (Hornibrook)

Plate 1, Figs. 18-20

Globigerina angiporoides Hornibrook, 1965, p. 835, figs. 1a-i and 2.

Discussion: Subbotina angiporoides is a persistent taxon throughout much of the uppermost Eocene-lower Oligocene of Hole 628A. In Hole $803 \mathrm{D}$, specimens of $S$. angiporoides are poorly developed and numerous questionable occurrences are noted. Its LO is in the upper part of Zone P20 in Hole 803D.

Subbotina? eocaena s.l. Gümbel

Plate 2, Figs. 7-11

Globigerina eocaena Gümbel, 1868, p. 662, pl. 2, figs. 109a-b; Hagn and Lindenberg, 1969, p. 236, pl. 1, figs. 1-6; Poore and Brabb, 1977, pp. 255-256, pl. 4, figs. 10-12.

Discussion: For the purposes of this study, large globigerinids with four chambers in the final whorl and an arched umbilical aperture bordered by an imperforate rim or thin lip are lumped under the concept of Subbotina? eocaena s.l. (also see discussions by Stainforth et al., 1975, and Poore and Brabb, 1977). The chambers in S.? eocaena are more inflated and the test is more lobate than the compact quadrilobate tests of Globigerina euapertura, G. pseudovenezuelana, and "Turborotalia" ampliapertura. S.? eocaena differs further from Globigerina euapertura in having a narrower and higher arched aperture and less embracing chambers. It differs from $S$.? yeguaensis in lacking a distinct toothlike apertural lip. S.? eocaena s.l. ranges throughout the lower Oligocene Zone P20 in Hole 803D and into Subzone P21a in Hole 628A.

\section{Subbotina linaperta s.l. (Finlay)}

Plate 2, Figs. 1-6

Globigerina linaperta Finlay, 1939, p. 125, pl. 13, figs. 54-57.

Discussion: This taxon, as applied in this study, may include forms referable to Globigerina utilisindex Jenkins and Orr, with which it is gradational (see discussion by Jenkins and Orr, 1973). Subbotina linaperta s.l. ranges up into Zone P19 (lower Oligocene) in Holes 803D and 628A.

$$
\text { Subbotina? yeguaensis s.l. Wienzierl and Applin }
$$

Plate 3, Figs. 1-6

Globigerina yeguaensis Wienzierl and Applin, 1929, p. 408, pl. 43, figs. 1a-b; Bolli and Saunders, 1985, pp. 180-181, fig. 13.23.

Discussion: We follow Bolli and Saunders (1985) in placing Globigerina galavisi Bermudez in synonymy with Subbotina? yeguaensis. S.? yeguaensis s.l. differs from $S$.? eocaena s.l. in possessing a definite toothlike apertural flap. This taxon ranges throughout the Oligocene of both Holes $628 \mathrm{~A}$ and 803D. Specimens form the upper Oligocene Zone P22 have as many as five chambers in the final whorl and a wider umbilicus. Such specimens are transitional with early forms of the Dentoglobigerina altispira group (Cushman and Jarvis).

\section{Tenuitella gemma (Jenkins)}

Plate 6, Figs. 6 and 11-13

Globorotalia gemma Jenkins, 1966, p. 115, fig. 11, nos. 97-103.

Discussion: We agree with Jenkins (1966) and Li Qianyu (1987) that Tenuitella gemma is not a junior synonym of Globigerina postcretacea Myatliuk. T. gemma is gradational with Tenuitellinata angustiumbilicata in the lower Oligocene.

\section{Tenuitellinata angustiumbilicata (Bolli)} Plate 6, Figs. 4-5

Globigerina ciperoensis angustiumbilicata Bolli, 1957b, p. 109, pl. 22, figs. 12-13; Bolli and Saunders, 1985, pp. 182-183.

Discussion: We follow Li Qianyu (1987) in placing Globigerina angustiumbilicata in the genus Tenuitellinata. This taxon is microperforate and is therefore phylogenetically unrelated to Globigerina ciperoensis. T. angustiumbilicata is gradational with Tenuitella gemma in the lower Oligocene. Gradational specimens are illustrated on Plate 6, Figures 7-10. Clear distinction between the two taxa is based on the position of the aperture.

\section{"Turborotalia" ampliapertura (Bolli)} Plate 4, Figs. 3-8

Globigerina ampliapertura Bolli, 1957b, p. 108, pl. 22, figs. 6a-c; Poore and Brabb, 1977, p. 255, pl. 1, figs. 7-9. 
Discussion: "Turborotalia" ampliapertura differs from Globigerina euapertura in having a higher arched aperture that is nearly circular in shape. A gradational form is illustrated on Plate 4, Figure 9. Only forms displaying such a distinct apertural shape are assigned to "T." ampliapertura. "T." ampliapertura is distinguished from Subbotina? eocaena s.l. in having a more compact test and an umbilical aperture without a lip.

\section{Turborotalia cerroazulensis (Cole)}

Plate 1, Figs. 7-8

Globigerina cerroazulensis Cole, 1928, p. 217, pl. 1, figs. 11-13.

Turborotalia cerroazulensis cerroazulensis (Cole) Toumarkine and Luterbacher, 1985 , p. 137 , figs. $34.3-4$ and $36.16-18$.

Discussion: A gradational specimen between Turborotalia cerroazulensis and $T$. cocoaensis is illustrated on Plate 1, Figures 1 and 6.

Turborotalia cocoaensis (Cushman)

Plate 1, Figs. 2-3

Globorotalia cocoaensis Cushman, 1928, p. 75, pl. 10, figs. 3a-c.

Turborotalia cerroazulensis cocoaensis (Cushman) Toumarkine and Luterbacher, 1985 , p. 138, figs. 34.2 and 36.10-12.

Discussion: A gradational specimen between Turborotalia cerroazulensis and T. cocoaensis is illustrated on Plate 1, Figures 1 and 6.

\section{Turborotalia cunialensis (Toumarkine and Bolli)}

Globorotalia cerroazulensis cunialensis Toumarkine and Bolli, 1970, p. 144. pl. 1, fig. 37 .

Turborotalia cerroazulensis cunialensis (Toumarkine and Bolli) Toumarkine and Luterbacher, 1985, p. 138, figs. 34.1 and $36.1-6$.

Discussion: A gradational specimen between Turborotalia cocoaensis and T. cunialensis is illustrated on Plate 1, Figures 4 and 5.

Turborotalia increbescens (Bandy)

Plate 4, Figs. 1-2

Globigerina increbescens Bandy, 1949, p. 120, pl. 23, figs. 3a-c.

Discussion: Turborotalia increbescens is gradational with "Turborotalia" ampliapertura. T. increbescens ranges throughout much of basal Oligocene Zone P18 in Holes 628A and 803D.

Turborotalia pomeroli (Toumarkine and Bolli) Plate 1, Fig. 10

Globorotalia cerroazulensis pomeroli Toumarkine and Bolli, 1970, p. 140, pl. 1 fig. 13.

Turborotalia cerroazulensis pomeroli (Toumarkine and Bolli) Toumarkine and Luterbacher, 1985, p. 137, figs. 34.9 and 35.4-9.

Discussion: A gradational specimen between Turborotalia pomeroli and T. cerroazulensis is illustrated on Plate 1, Figure 9.

\section{REFERENCES}

Austin, J.A., Jr., Schlager, W., Palmer, A.A., et al., 1986. Proc. ODP, Init. Repts., 101: College Station, TX (Ocean Drilling Program).

Bandy, O.L., 1949. Eocene and Oligocene foraminifera from Little Stave Creek, Clarke County, Alabama. Bull. Am. Paleontol., 32:1-210.

Berggren, W.A., 1969. Rates of evolution in some Cenozoic planktonic foraminifera. Micropaleontology, 15:351-365.

Berggren, W.A., Kent, D.V., and Flynn, J.J., 1985. Jurassic to Paleogene: Part 2. Paleogene geochronology and chronostratigraphy. In Snelling, N.J. (Ed.), The Chronology of the Geological Record. Geol. Soc. London Mem., 10:211-260.

Berggren, W.A., and Miller, K.G., 1988. Paleogene tropical foraminiferal biostratigraphy and magnetobiochronology. Micropaleontology, 34:362-380.

Blow, W.H., 1959. Age correlation and biostratigraphy of the Upper Tocuyo (San Lorenzo) and Pozón formations, Eastern Falcon, Venezuela. Bull. Am. Paleontol., 39:67-251.
1969. Late middle Eocene to Recent planktonic foraminiferal biostratigraphy. In Brönniman, P., and Renz, H.H. (Eds.), Proc. Ist Int. Conf. Planktonic Microfossils, 1:199-422.

Blow, W.H., and Banner, F.T., 1962. Part 2: The Tertiary (upper Eocene to Aquitanian) Globigerinaceae. In Eames, F.E., Banner, F.T., Blow, W.H., and Clarke, W.J. (Eds.), Fundamentals of Mid-Tertiary Stratigraphical Correlation: Cambridge (Cambridge Univ. Press), 61-151.

Boersma, A., and Shackleton, N.J., 1977. Oxygen and carbon isotope record through the Oligocene, DSDP Site 366, equatorial Atlantic. In Lancelot, Y., Seibold, E., et al., Init. Repts. DSDP, 41: Washington (U. S. Govt. Printing Office), 957-962.

Bolli, H.M., 1957a. Planktonic foraminifera from the Eocene Navet and San Fernando formations of Trinidad, B.W.I. Bull. U.S. Nat. Mus., 215:155-172. , 1957b. Planktonic foraminifera from the Oligocene-Miocene Cipero and Lengua formations of Trinidad, B.W.I. In Loeblich, A.R., Jr., Tappan, H., Beckmann, J.P., Bolli, H.M., Gallitelli, E.M., and Troelsen, J.C. (Eds.), Studies in Foraminifera. Bull. U.S. Nat. Mus., 215:97-123.

, 1966. Zonation of Cretaceous to Pliocene marine sediments based on planktonic foraminifera. Bol. Informativo Asoci. Venezolana Geol. Min., Petrol., 9:3-32.

Bolli, H.M., Loeblich, A.R., Jr., and Tappan, H., 1957. Planktonic foraminiferal families Hantkeninidae, Orbulinidae, Globorotaliidae and Globotruncanidae. Bull. U.S. Nat. Mus., 215:3-50.

Bolli, H.M. and Saunders, J.B., 1985. Oligocene to Holocene low latitude planktonic foraminifera. In Bolli, H.M., Saunders, J.B., and Perch-Nielsen, K. (Eds.), Plankton Stratigraphy: Cambridge (Cambridge Univ. Press), 155-262.

Borsetti, A.M., 1959. Tre nuovi foraminiferi planctonici dell' Oligocene piacentino. G. Geol., 27:205-212.

Chapman, F., Parr, W.J., and Collins, A.C., 1934. Tertiary foraminifera of Victoria, Australia. The Balcombian deposits of Port Phillip; Part III. J. Linn. Soc. London, Zool., 38:553-577.

Cifelli, R., 1969. Radiation of Cenozoic planktonic foraminifera. Syst. Zool., $18: 154-168$

Cole, W.S., 1927. A foraminiferal fauna from the Guayabal Formation in Mexico. Bull. Am. Paleontol., 14:1-46.

, 1928. A foraminiferal fauna from the Chapapote Formation in Mexico. Bull. Am. Paleontol., 14:3-32.

Corliss, B.H., Aubry, M.-P., Berggren, W.A., Fenner, J.M., Keigwin, L.D., and Keller, G., 1984. The Eocene/Oligocene boundary event in the deep sea. Science, 226:806-810.

Cushman, J.A., 1925. A new genus of Eocene foraminifera. Proc. U.S. Natl. Mus., 66:1-4.

1928. Additional foraminifera from the upper Eocene of Alabama. Contrib. Cushman Lab. Foraminiferal Res., 4:73-39.

Cushman, J.A., and Bermudez, P.J., 1937. Further new species of foraminifera from the Eocene of Cuba. Contrib. Cushman Lab. Foraminiferal Res., $13: 1-29$.

Cushman, J.A., and Ellisor, A.O., 1939. New species of foraminifera from the Oligocene and Miocene. Contrib. Cushman Lab. Foraminiferal Res., $15: 1-14$.

Cushman, J.A., and Ponton, G.M., 1932. The foraminifera of the upper, middle and part of the lower Miocene of Florida. Bull. Florida State Geol. Surv., 9:7-147.

Finlay, H.J., 1939. New Zealand foraminifera: key species in stratigraphy. No. 2. Trans. R. Soc. N.Z., 69:89-128.

Gümbel, C.W., 1868. Beiträge zur Foraminiferenfauna der Nordalpinen, älteren Eocängebilde oder der kressenberger Nummulitenschichten. Abh. K Bayer. Akad. Wiss., II Cl., 10:579-730.

Hagn, H., and Lindenberg, H.G., 1969. Revison der von C.W. Gümbel 1868 aus dem Eozän des bayerischen Alpenvorlandes beschreibenen planktonischen Foraminiferen. In Brönniman, P., and Renz, H.H. (Eds.), Proc. 1st Int. Conf. Planktonic Microfossils, 1:229-249.

Haq, B.U., Hardenbol, J., and Vail, P.R., 1987. The new chronostratigraphic basis of Cenozoic and Mesozoic sea level cycles. Spec. Publ., Cushman Found. Foraminiferal Res., 24:7-13.

Haq, B.U., Premoli-Silva, I., and Lohmann, G.P., 1977. Calcareous planktonic paleobiogeographic evidence for major climatic fluctuations in the Early Cenozoic Atlantic Ocean. J. Geophys. Res., 82:3861-3876.

Hess, J., Stott, L.D., Bender, M.L., Kennett, J.P., and Schilling, J.-G., 1989. The Oligocene marine microfossil record: age assessments using strontium isotopes. Paleoceanography, 4:655-679. 
Hornibrook, N. de B., 1961. Tertiary foraminifera from Oamaru District (N.Z.). Part 1-Systematics and distribution. Bull. N.Z. Geol. Surv., 34:1-192. , 1965. Globigerina angiporoides n. sp. from the upper Eocene and lower Oligocene of New Zealand. N.Z. J. Geol. Geophys., 8:834-838.

Howe, H.V., and Wallace, W.E., 1932. Foraminifera of the Jackson Eocene at Danville Landing on the Ouachita Catahoula Parish, Louisiana. Geol. Bull. Dept. Conserv. Louisiana, 2:1-118.

Huber, B.T., 1991. Paleogene and early Neogene planktonic foraminifer biostratigraphy of Sites 738 and 744, Kerguelen Plateau (southern Indian Ocean). In Barron, J., Larsen, B., et al., Proc. ODP, Sci. Results, 119: College Station, TX (Ocean Drilling Program), 427-450.

Jenkins, D.G., 1960. Planktonic foraminifera from the Lakes Entrance oil shaft, Victoria, Australia. Micropaleontology, 6:345-371.

, 1966. Planktonic foraminiferal zones and new taxa from the Danian to lower Miocene of New Zealand. N.Z. J. Geol. Geophys., 8:1088-1126.

, 1985. Southern mid-latitude Paleocene to Holocene planktic foraminifera. In Bolli, H.M., Saunders, J.B., and Perch-Nielsen, K. (Eds.), Plankton Stratigraphy: Cambridge (Cambridge Univ. Press.), 263-282.

Jenkins, D.G., and Orr, W.N., 1973. Globigerina utilisindex n. sp. from the upper Eocene and Oligocene of the eastern equatorial Pacific. J. Foraminiferal Res., 3:133-136.

Keigwin, L.D., 1980. Palaeoceanographic change in the Pacific at the Eocene/ Oligocene boundary. Nature, 287:722-725.

Keigwin, L.D., and Keller, G., 1984. Middle Oligocene cooling from equatorial Pacific DSDP Site 77B. Geology, 12:16-19.

Keller, G, and Barron, T.A., 1983. Paleoclimatic implications of Miocene deep-sea hiatuses. Geol. Soc. Am. Bull., 94:590-613.

Keller, G., Herbert, T., Dorsey, R., D'Hondt, S., Johnsson, M., and Chi, W.R., 1987. Global distribution of late Paleogene hiatuses. Geology, 15:199-203.

Kennett, J.P., 1977. Cenozoic evolution of Antarctic glaciation, the CircumAntarctic Ocean, and their impact on global paleoceanography. J. Geophys. Res., 82:3843-3860.

, 1978. The development of planktonic biogeography in the Southern Ocean during the Cenozoic. Mar. Micropaleontol., 3:301-345.

Kennett, J.P., and Shackleton, N.J., 1976. Oxygen isotope evidence for the development of the psychrosphere $38 \mathrm{myr}$ ago. Nature, 260:513-515.

Kennett, J.P., and Srinivasan, M.S., 1983. Neogene Planktonic Foraminifera: Stroudsberg, PA (Hutchinson and Ross).

Kennett, J.P., and Stott, L.D., 1990. Proteus and proto-oceanus: ancestral Paleogene oceans as revealed from Antarctic stable isotope results: ODP Leg 113. In Barker, P.F., Kennett, J.P., et al., Proc. ODP, Sci. Results, 113: College Station, TX (Ocean Drilling Program), 865-880.

, 1991. Abrupt deep-sea warming, paleoceanographic changes and benthic extinctions at the end of the Paleocene. Nature, 353:225-229.

Koch, R., 1926. Millelertiäre Foraminiferen aus Bulongan, Ost-Borneo. Eclogae Geol. Helv., 19:722-751.

Kroenke, L.W., Berger, W.H., Janecek, T.R., et al., 1991. Proc, ODP, Init. Repts., 130: College Station, TX (Ocean Drilling Program).

Li Qianyu, 1987. Origin, phylogenetic development and systematic taxonomy of the Tenuitella plexus (Globigerinitidae, Globigerinina). J. Foraminiferal Res., 17:321-332.

Matthews, R., and Poore, R.Z., 1980. Tertiary ${ }^{18} \mathrm{O}$ record and glacio-eustatic sea-level fluctuations. Geology, 8:501-504.

Miller, K.G., and Curry, W.B., 1982. Eocene to Oligocene benthic foraminiferal isotopic records in the Bay of Biscay. Nature, 96:347-350.

Miller, K.G., and Fairbanks, R.G., 1985. Oligocene to Miocene carbon isotope cycles and abyssal circulation changes. In Sundquist, E.T., and Broecker W.S. (Eds.), The Carbon Cycle and Atmospheric $\mathrm{CO}_{2}$ : Natural Variations Archean to Present. Am. Geophys. Union, Monogr. Ser., 32:469-486.

Miller, K.G., Fairbanks, R.G., and Mountain G.S., 1987. Tertiary oxygen isotope synthesis, sea level history, and continental margin erosion. Paleoceanography, 2:1-19.
Miller, K.G., Feigenson, M.D., Kent, D.V., and Olsson, R.K., 1988. Upper Eocene to Oligocene isotope $\left({ }^{87} \mathrm{Sr} /{ }^{86} \mathrm{Sr}, \delta^{18} \mathrm{O}, \delta^{13} \mathrm{C}\right)$ standard section, Deep Sea Drilling Project Site 522. Paleoceanography, 3:223-233.

Moran, M.J., and Watkins, D.K., 1988. Oligocene calcareous nannofossil biostratigraphy from Leg 101, Site 628, Little Bahama Bank Slope. In Austin, J.A., Jr., Schlager, W., Palmer, A.A., et al., Proc. ODP, Sci. Results, 101: College Station, TX (Ocean Drilling Program), 87-103.

Myatliuk, E.V., 1950. The stratigraphy of the flysch deposits of the northern Carpathian Mountains according to the foraminiferal faunas. Trudy VNIGRI, 51:225-287. (in Russian)

Nocchi, M., Amici, E., and Premoli Silva, I., 1991. Planktonic foraminiferal biostratigraphy and paleoenvironmental interpretation of Paleogene faunas from the subantarctic transect, Leg 114. In Ciesielski, P.F., Kristoffersen, Y., et al., Proc. ODP, Sci. Results, 114: College Station, TX (Ocean Drilling Program), 233-273.

Palmer, D.K., 1934. The foraminiferal genus Guembelina in the Tertiary of Cuba. Mem. Soc. Cubana Hist. Nat., 8:73-76.

Parker, F.L., 1962: Planktonic foraminiferal species in Pacific sediments. Micropaleontology, 8:219-254.

Pijpers, P.J., 1933. Geology and paleontology of Bonaire (D.W.I.). Univ. Utrecht Geogr. Geol. Med., Phys.-Geol. Reeks, 8:1-103.

Poore, R.Z., 1984. Middle Eocene through Quaternary planktonic foraminifers from the Southern Angola Basin. In Hsü, K.J., LaBrecque, J.L., et al., Init. Repts. DSDP, 73: Washington (U.S. Govt. Printing Office), 429-448.

Poore, R.Z., and Brabb, E.E., 1977. Eocene and Oligocene planktonic foraminifera from the upper Butano Sandstone and type San Lorenzo Formation, Santa Cruz Mountains, California. J. Foraminiferal Res., 7:249-277.

Poore, R.Z., and Bybell, L.M., 1988. Eocene to Miocene biostratigraphy of New Jersey Core ACGS \#4: implications for regional stratigraphy. U.S. Geol. Surv. Bull., No. 1829.

Sager, W.W., 1988. Paleomagnetism of Ocean Drilling Program Leg 101 sediments: magnetostratigraphy, magnetic diagenesis, and paleolatitudes. In Austin, J.A., Jr., Schlager, W., Palmer, A.A., et al., Proc. ODP, Sci. Results, 101: College Station, TX (Ocean Drilling Program), 327-360.

Savin, S.M., Douglas, R.G., and Stehli, F.G., 1975. Tertiary marine paleotemperatures. Geol. Soc. Am. Bull., 86:1499.

Shackleton, N.J., and Kennett, J.P., 1975. Paleotemperature of the Cenozoic and the initiation of Antarctic glaciation: oxygen and carbon isotope analyses in DSDP Sites 277, 279, and 281. In Kennett, J.P., Houtz, R.E., et al., Init. Repts. DSDP, 29: Washington (U.S. Govt. Printing Office), 743-756.

Spezzaferri, S., 1991. Evolution and taxonomy of the Paragloborotalia kugleri (Bolli) lineage. J. Foraminiferal Res., 21:313-318.

Stainforth, R.M., Lamb, J.L., Luterbacher, H., Beard, J.H., and Jeffords, R.M. 1975. Cenozoic planktonic foraminiferal zonation and characteristics of index forms. Univ. Kansas Paleontol. Contrib., Article 62.

Stott, L.D., and Kennett, J.P., 1990. Antarctic Paleogene planktonic foraminifer biostratigraphy: ODP Leg 113, Sites 689 and 690. In Barker, P.F., Kennett, J.P., et al., Proc. ODP, Sci. Results, 113: College Station, TX (Ocean Drilling Program), 549-569.

Toumarkine, M., and Bolli, H.M., 1970. Evolution de Globorotalia cerroazulensis (Cole) dans l'Eocène moyen supérior de Possagno (Italie). Rev. Micropaleontol., 13:131-145.

Toumarkine, M., and Luterbacher, H.P., 1985. Paleocene and Eocene planktonic foraminifera. In Bolli, H.M., Saunders, J.B., and Perch-Nielsen, K. (Eds.), Plankton Stratigraphy: Cambridge (Cambridge Univ. Press), 87-154.

Wienzerl, L.L., and Applin, E.R., 1929. The Claiborne Formation on the coastal domes. J. Paleontol., 3:384-410.

Date of initial receipt: 6 January 1992

Date of acceptance: 22 April 1992

Ms 130B-012 


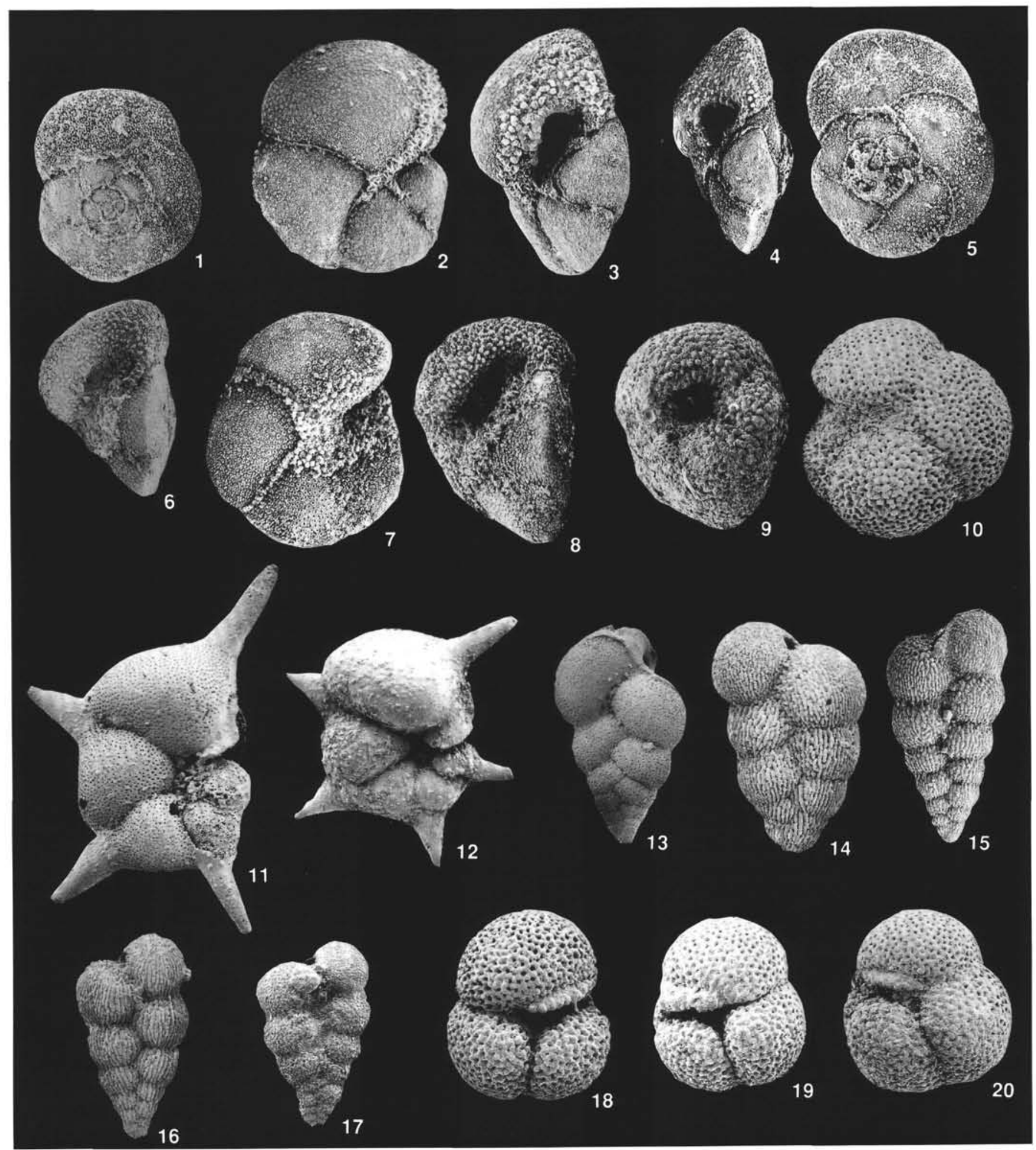

Plate 1. 1, 6. Turborotalia cerroazulensis-cocoaensis transition; Sample 101-628A-29X-1, 100-102 cm, $\times 70$. 2-3. Turborotalia cocoaensis; Sample 101$628 \mathrm{~A}-29 \mathrm{X}-\mathrm{CC}, \times 100$. 4-5. Turborotalia cocoaensis-cunialensis transition; Sample 101-628A-29X-2, 30-32 cm, $\times 100$. 7-8. Turborotalia cerroazulensis; Sample 101-628A-29X-1, 100-102 cm, $\times 70$. 9. Turborotalia cerroazulensis-pomeroli transition; Sample 130-803D-59X-1, 44-46 cm, $\times 100$. 10. Turborotalia pomeroli; Sample 101-628A-29X-1, 100-102 cm, $\times 100$. 11. Hantkenina alabamensis; Sample 101-628A-29X-CC, $\times 100 . \quad 12$. Hantkenina cf. H. alabamensis; Sample 101-628A-29X-CC, $\times 70$. 13. Chiloguembelina cf. C. martini; Sample 101-628A-29X-CC, $\times 100$. 14-17. Chiloguembelina cubensis; (14) Sample 130-803D-47X-1, 51-53 cm, $\times 150$; (15) Sample 101-628A-26X-1, 74-76 cm, $\times 150$; (16) Sample 101-628A-16H-3, 100-102 cm, $\times 200$; (17) Sample 130-803D57X-3, 46-48 cm, $\times 100$. 18-20. Subbotina angiporoides; (18) Sample 101-628A-27X-1, 100-102 cm, $\times 100$; (19) Sample 130-803D-54X-1, 41-43 cm, $\times 100$; (20) Sample 101-628A-26X-1, 74-76 cm, $\times 100$. 


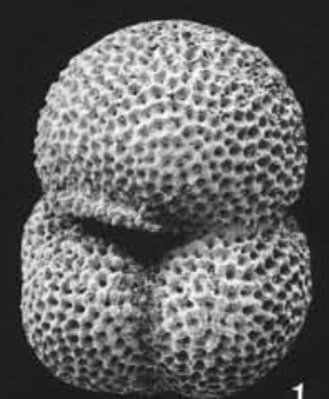

1
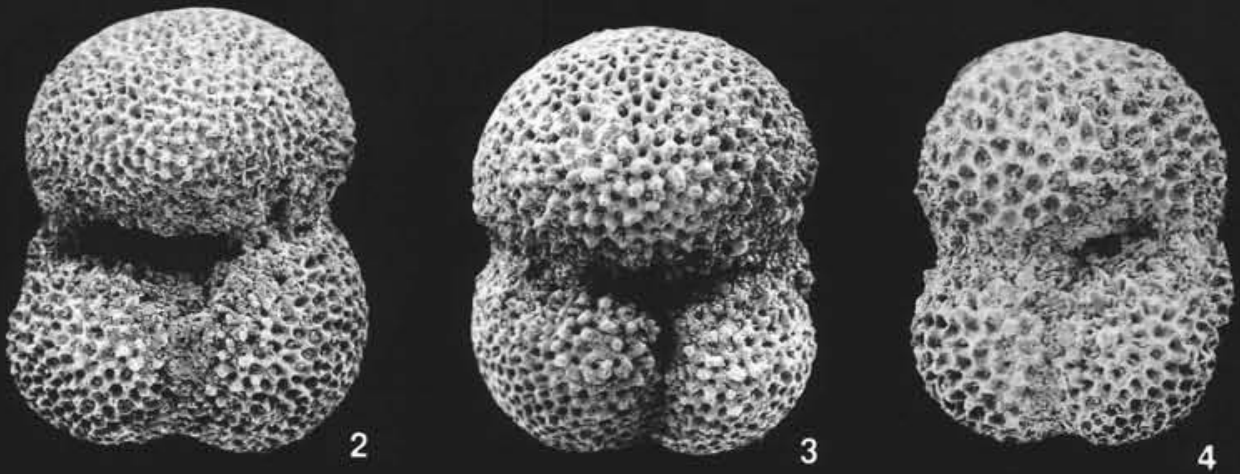

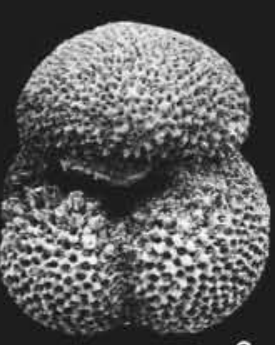

6

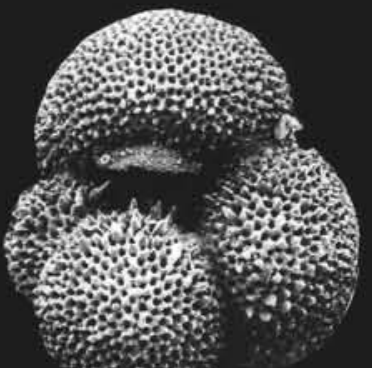

7

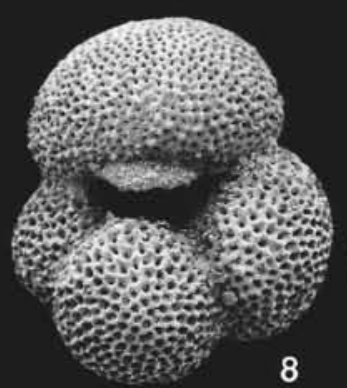

8
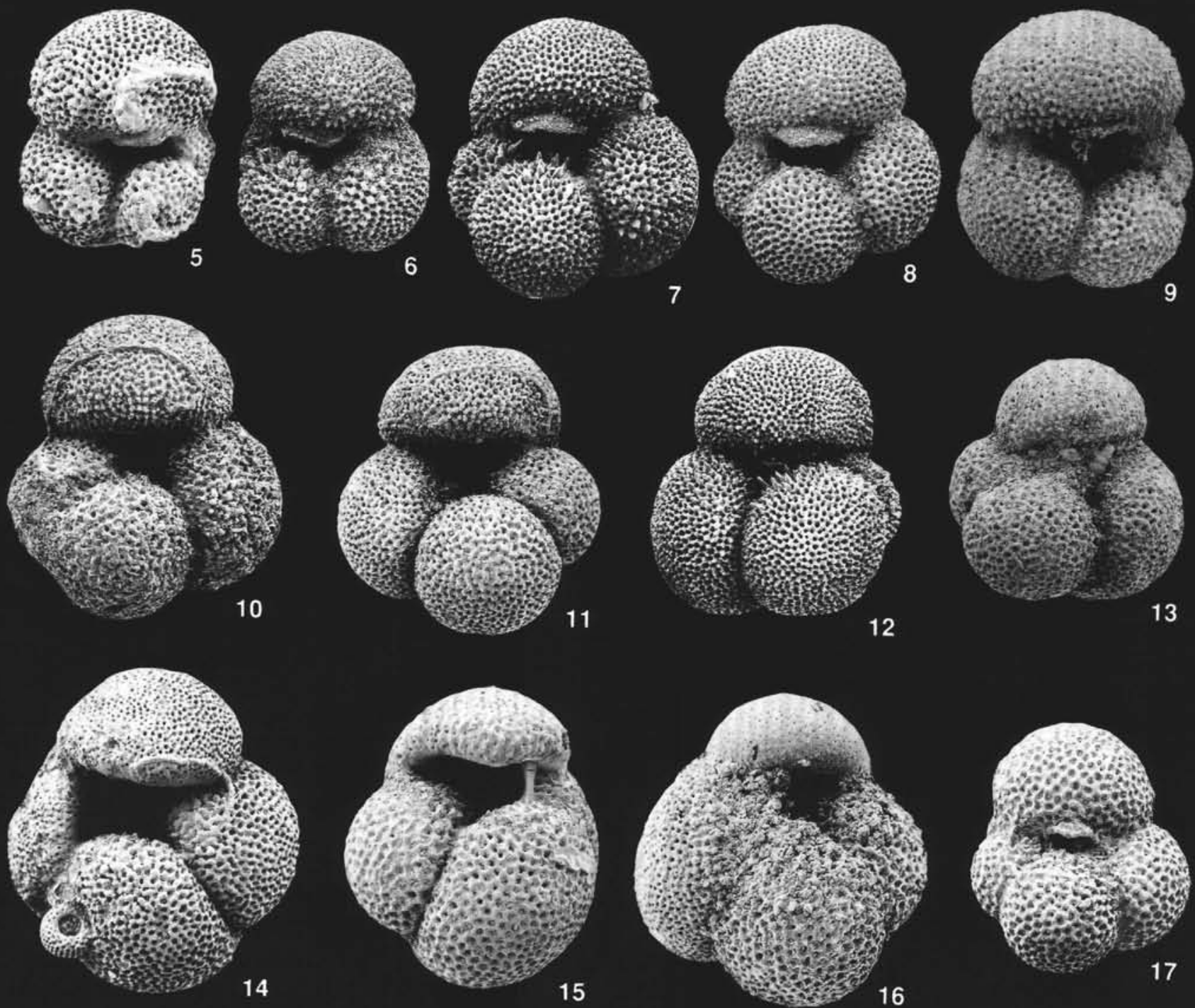

Plate 2. 1-6. Subbotina linaperta s.I.; (1) Sample 101-628A-28X-1, 100-102 cm, $\times 100$; (2) Sample 101-628A-29X-2, 30-32 cm, $\times 100$; (3) Sample 101-628A26X-CC, $\times 100$; (4) Sample 101-628A-29X-1, 100-102, x100; (5) Sample 130-803D-54X-3, 57-59 cm, x70; (6) Sample 101-628A-28X-CC, $\times 70 . \quad 7-11$. Subbotina? eocaena; (7) Sample 101-628A-29X-CC, $\times 70$; (8) Sample 101-628A-27X-1, 100-102 cm, ×70; (9) Sample 101-628A-26X-CC, $\times 70$; (10) Sample 101-628A-26X-2, 30-32 cm, $\times 70$; (11) Sample 101-628A-28X-CC, $\times 70 . \quad$ 12-17. Globigerina/Subbotina spp.; (12) Sample 101-628A-29X-CC, $\times 70 ;(13)$ Sample 101-628A-25X-CC, $\times 100$; (17) Sample 130-803D-58X-CC $\times 70$ - interval uncertain, $\times 70$; (15) Sample 130-803D-47X-5, 48-50 cm, $\times 100$; (16) Sample 


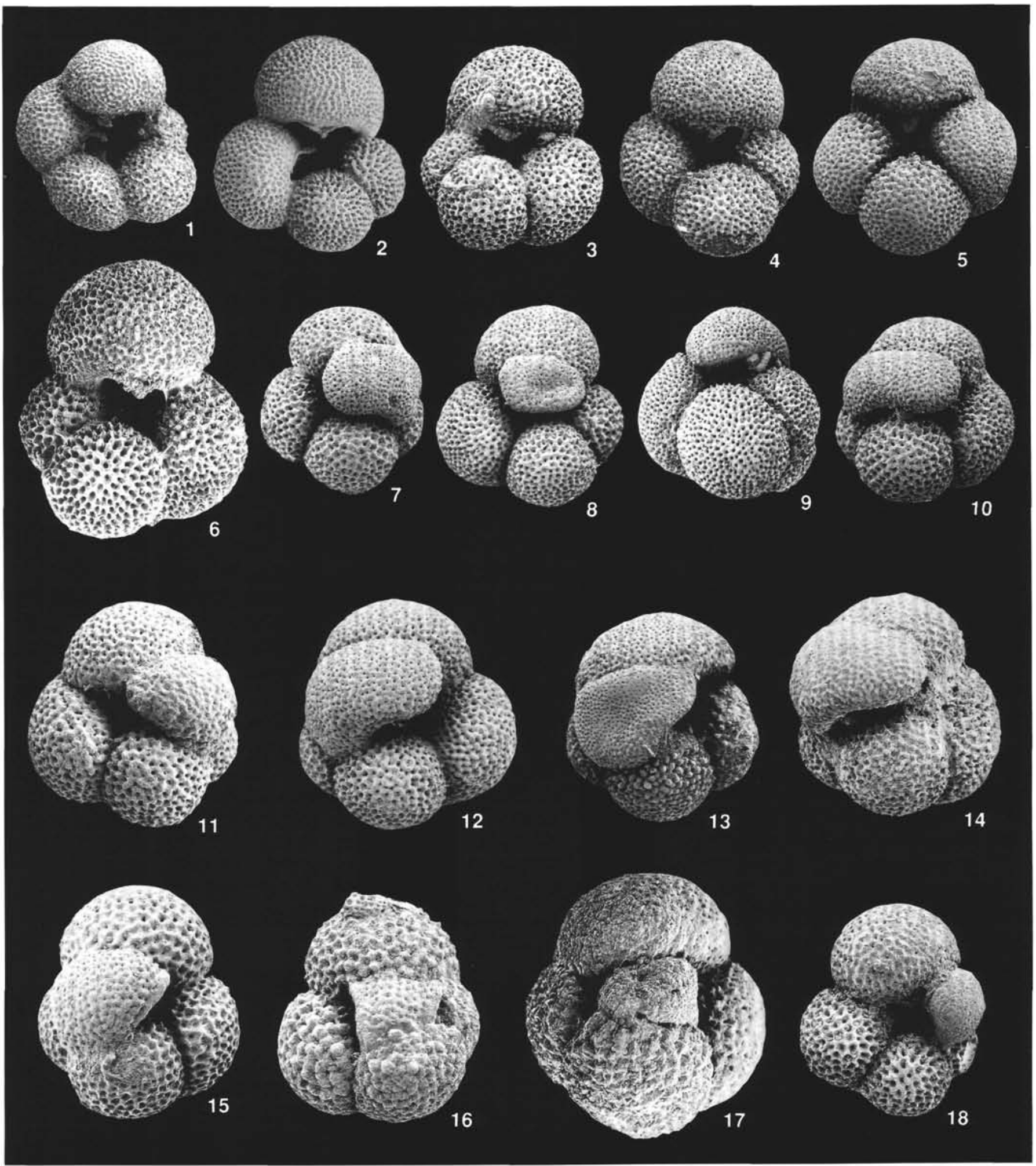

Plate 3. 1-6. Subbotina? yeguaensis; (1) Sample 101-628A-16H-3, 100-102 cm, $\times 70$; (2) Sample 101-628A-16H-3, 100-102 cm, $\times 70$; (3) Sample 101-628A29X-CC, $\times 70$; (4) Sample 101-628A-27X-1, 100-102 cm, x70; (5) Sample 130-803D-43X-1, 49-51 cm, $\times 70$; (6) Sample 101-628A-28X-CC, $\times 100 \quad 7-14$. Globigerina gortanii; (7) Sample 130-803D-44X-5, 68-70 cm, x70; (8) Sample 101-628A-27X-1, 100-102 cm, ×70; (9) Sample 101-628A-27X-1, 100-102 cm, $\times 70$; (10) Sample 101-628A-28X-CC, $\times 70$; (11) Sample 130-803D-36X-5, 50-52 cm, $\times 100$; (12) Sample 101-628A-22X-CC, $\times 70$; (13) Sample 130-803D-51X-CC, $\times 70$; (14) Sample 101-628A-18H-5, 100-102 cm, $\times 100$. 15. Catapsydrax unicavus; Sample 130-803D-51X-CC, $\times 100.16-17$. Catapsydrax dissimilis; (16) Sample 130-803D-46X-3, 53-55 cm, ×100; (17) Sample 101-628A-17H-CC, $\times 100$. 18. Globorotaloides suteri; Sample 101-628A-18H-CC, $\times 100$. 


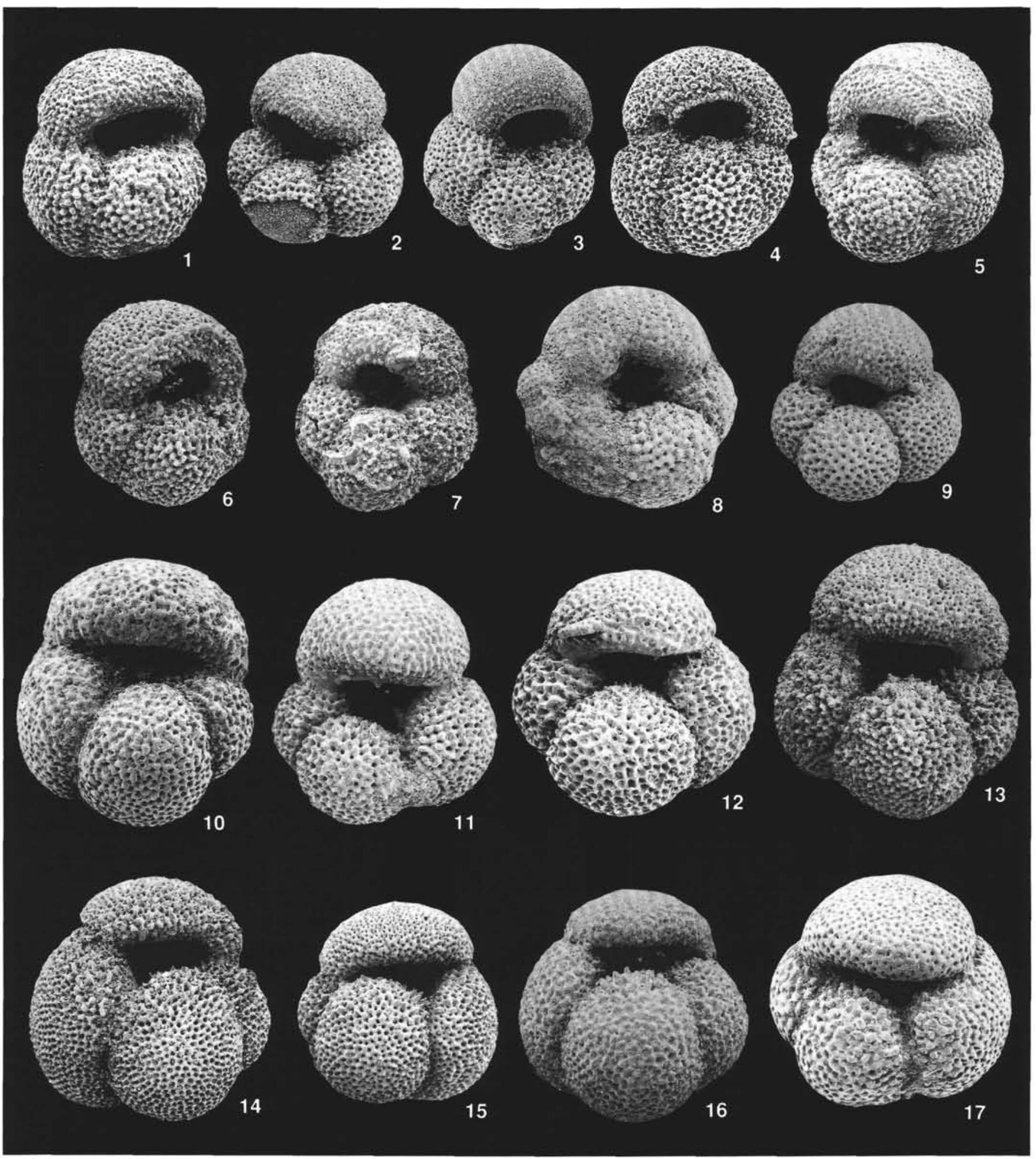

Plate 4. 1-2. Turborotalia increbescens; (1) Sample 130-803D-58X-CC, $\times 100$; (2) Sample 101-628A-58X-CC, $\times 100$. 3-8. "Turborotalia" ampliapertura; (3) Sample 101-628A-26X-1, 74-76 cm, ×100; (4) Sample 101-628A-26X-1, 74-76 cm, ×100; (5) Sample 130-803D-58X-CC, $\times 100$; (6) Sample 101-628A-26X-CC, $\times 100$; (7) Sample 101-628A-28X-1, 100-102 cm, $\times 100$; (8) Sample 130-803D-51X-3, 36-38 cm (last occurrence), $\times 100$. 9. "Turborotalia" ampliapertura/Globigerina euapertura transition; Sample 101-628A-23X-CC, $\times 70$. 10-13. Globigerina euapertura; (10) Sample 130-803D-58X-CC, $\times 100$; (11) Sample 130-803D-45X-CC, $\times 100$; (12) Sample 101-628A-25X-2, 12-14 cm, $\times 100$; (13) Sample 101-628A-25X-CC, $\times 70 . \quad 14$. Globigerina euapertura/Globigerina pseudovenezuelana transition; Sample 101-628A-26X-CC, $\times 70$. 15-17. Globigerina pseudovenezuelana; (15) Sample 101-628A-27X-1, 100-102 cm, $\times 70 ;(16)$ Sample 101-628A-17H-1, 100-102 cm, $\times 70$; (17) Sample 130-803D-57X-CC, $\times 100$. 

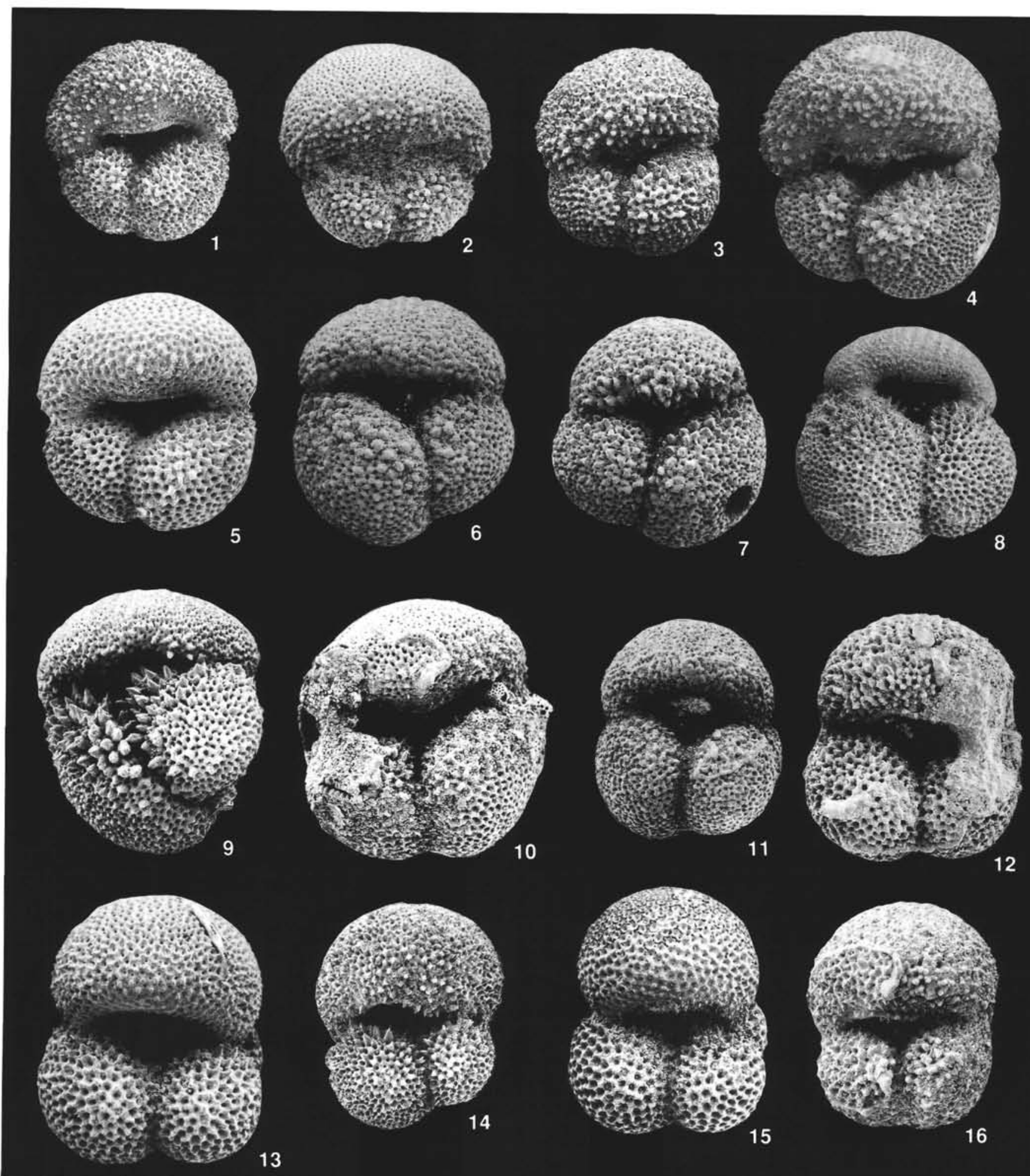

Plate 5. 1-5. Globigerina sellii; (1) Sample 101-628A-16H-CC, $\times 70$; (2) Sample 101-628A-26X-1, 74-76 cm, $\times 70$; (3) Sample 130-803D-36X-5, 50-52 cm, $\times 70$; (4) Sample 101-628A-17H-CC, $\times 70$; (5) Sample 101-628A-16H-1, 100-102 cm, $\times 100 . \quad 6-10$. Globigerina tripartita; (6) Sample 101-628A-24X-1, 100-102 $\mathrm{cm}, \times 70$; (7) Sample 101-628A-22X-5, 120-122 cm, $\times 70$; (8) Sample 101-628A-18H-5, 100-102 cm, $\times 70$; (9) Sample 130-803D-43X-5, 50-52 cm, $\times 70$; (10) Sample 130-803D-54X-3, 57-59 cm, $\times 100$. 11-16. Globigerina tapuriensis; (11) Sample 130-803D-58X-CC, $\times 70 ;$ (12) Sample 130-803D-48X-CC, $\times 100 ;(13)$ Sample 101-628A-26X-1, 74-76 cm, $\times 100$; (14) Sample 101-628A-21H-1, 100-102 cm, $\times 70$; (15) Sample 101-628A-26X-1, 74-76 cm, $\times 100$; (16) Sample 101-628A-28X-1, 100-102 cm, $\times 100$. 

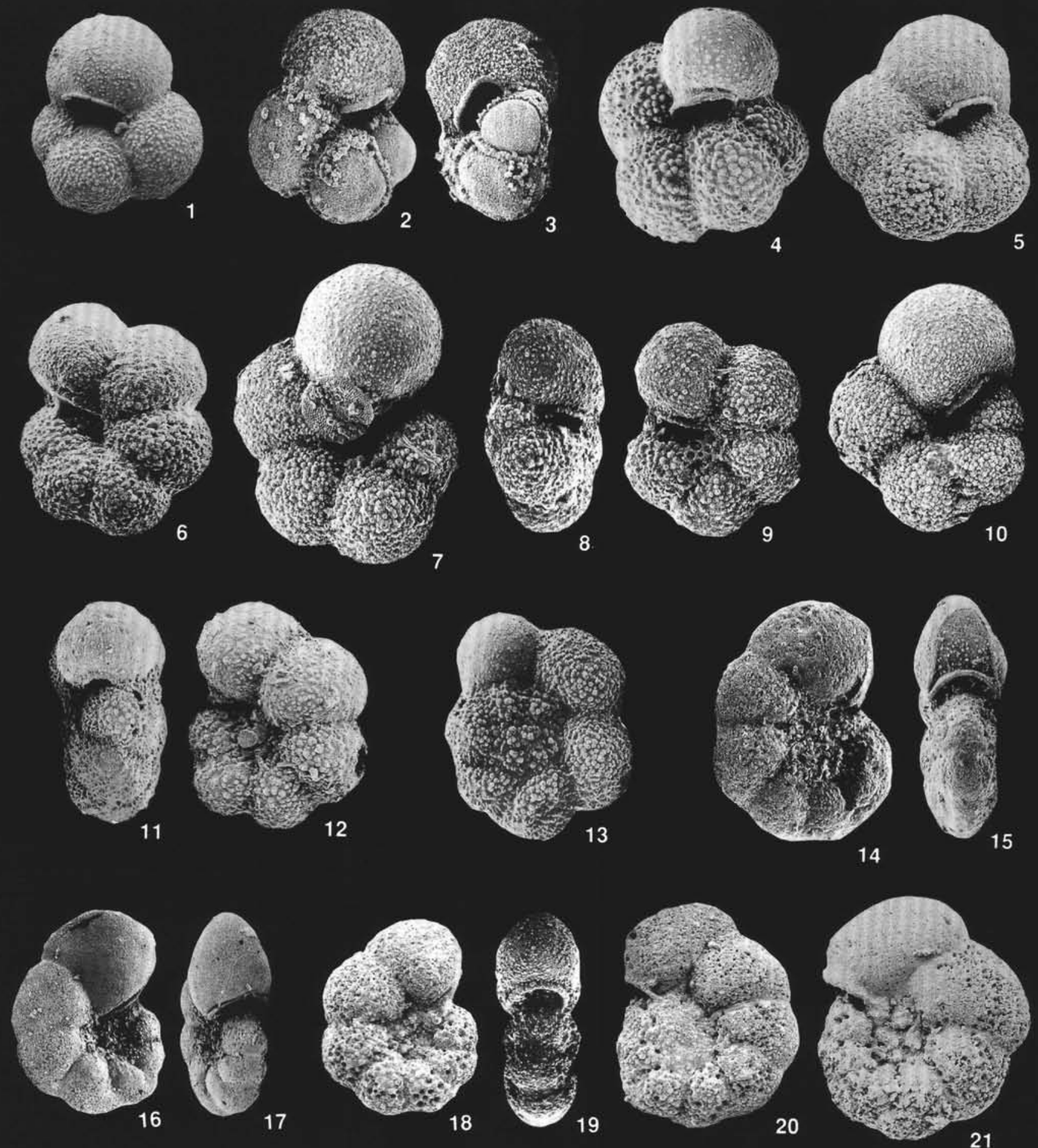

Plate 6. 1. Globigerinita glutinata s.1.; Sample 101-628A-18H-1, 100-102 cm, $\times 200$. 2-3. Tenuitella munda; Sample 130-803D-35X-5, 50-52 cm, $\times 150$. 4-5. Tenuitellinata angustiumbilicata; (4) Sample 101-628A-16H-CC, $\times 200$; (5) Sample 130-803D-51X-3,36-38 cm, $\times 200$. 6, 11-13. Tenuitella gemma; (6) Sample 130-803D-40X-CC, $\times 300$; (11-12) Sample 101-628A-26X-1, 74-76 cm, ×300; (13) Sample 101-628A-19H-1, 100-102 cm, ×300. 7-10. Tenuitellinata angustiumbilicata/Tenuitella gemma transition; (7) Sample 130-803D-53X-1, 55-57 cm, $\times 200$; (8-9) Sample 130-803D-54X-3, 57-59 cm, $\times 200$; (10) Sample 130-803D-54X-3, 57-59 cm, $\times 200$. 14-17. Pseudohastigerina micra; $(14-15)$ Sample 101-628A-29X-1, 100-102 cm, $\times 150$; (16-17) Sample 101-628A-29X-2, 30-32 cm, $\times 100$. 18-19. Pseudohastigerina cf. P. naguewichiensis; (18) Sample 130-803D-57X-1, 71-73 cm, $\times 200$; (19) Sample 101-628A-28X-CC, $\times 200$. 20-21. Pseudohastigerina aff. P. micra; (20) Sample 101-628A-27X-1, 100-102 cm, $\times 200$; (21) Sample 101-628A-27X-1, $100-102 \mathrm{~cm}, \times 200$. 


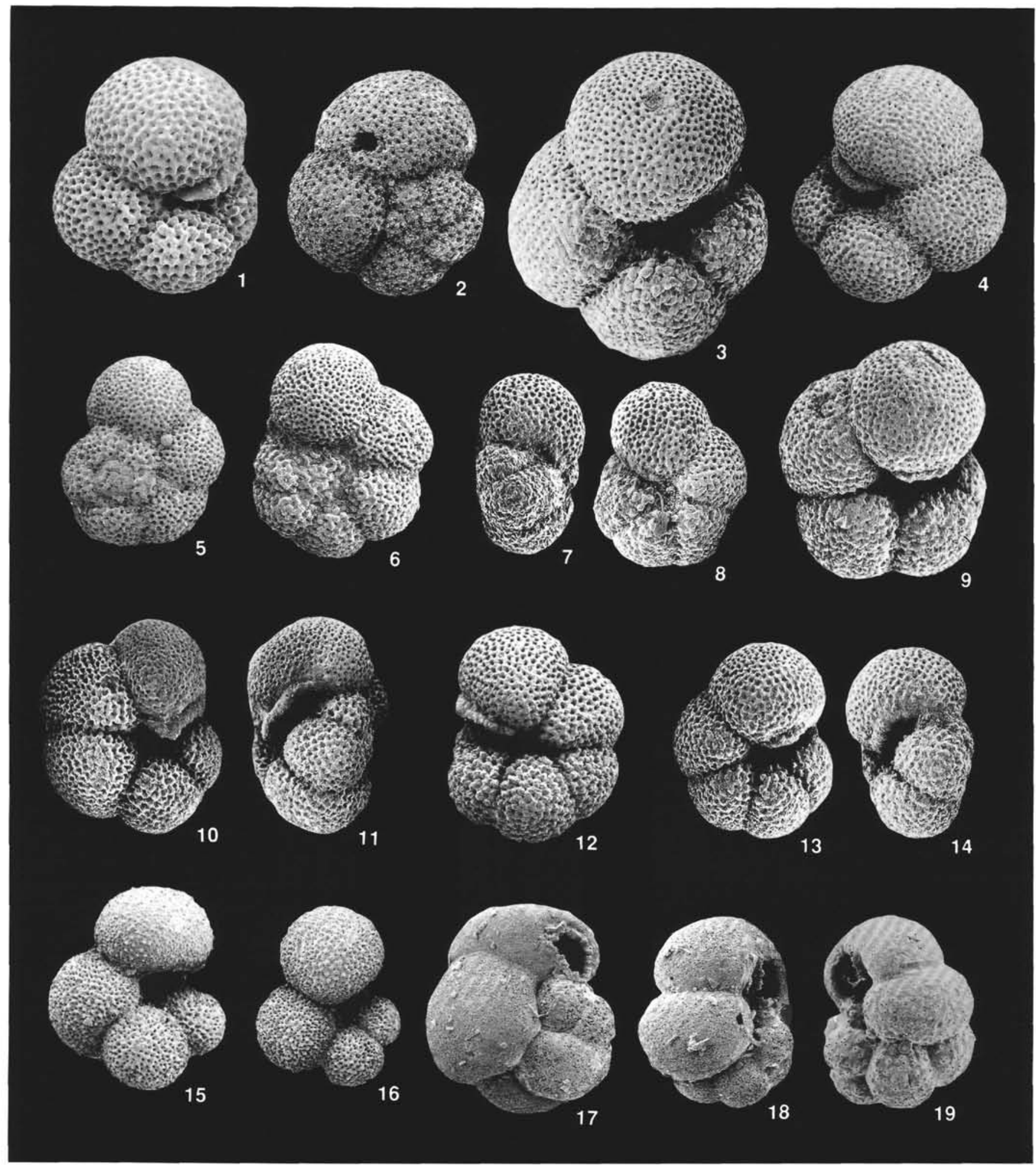

Plate 7. 1-2. Paragloborotalia nana; (1) Sample 101-628A-16H-1, 100-102 cm, $\times 150$; (2) Sample 101-628A-26X-1, 74-76 cm, $\times 150$. 3-4,9. Paragloborotalia opima; (3) Sample 130-803D-42X-CC, $\times 100$; (4) Sample 101-628A-21H-1, 100-102 cm, $\times 100$; (9) Sample 130-803D-48X-CC (first occurrence), $\times 100$. 5-8, 10-14. Paragloborotalia semivera/mayeri group; (5) Sample 101-628A-16H-5, 100-102 cm, $\times 100$; (6) Sample 130-803D-36X-CC, $\times 100$; (7-8) Sample 130-803D36X-CC, $\times 100$; (10-11) Sample 101-628A-16H-3, 100-102 cm, $\times 100$; (12) Sample 130-803D-36X-5, 50-52 cm, $\times 100$; (13-14) Sample 130-803D-40X-CC, $\times 100$. 15-16. Globigerinella obesa; (15) Sample 101-628A-17H-1, 100-102 cm, $\times 100$; (16) Sample 101-628A-18H-CC, $\times 100$. 17. Cassigerinella sp.; Sample 101-628A26X-CC, $\times 150$. 18-19. Cassigerinella chipolensis; (18) Sample 101-628A-26X-CC, $\times 200$; (19) Sample 101-628A-19H-1, $100-102 \mathrm{~cm}, \times 200$. 

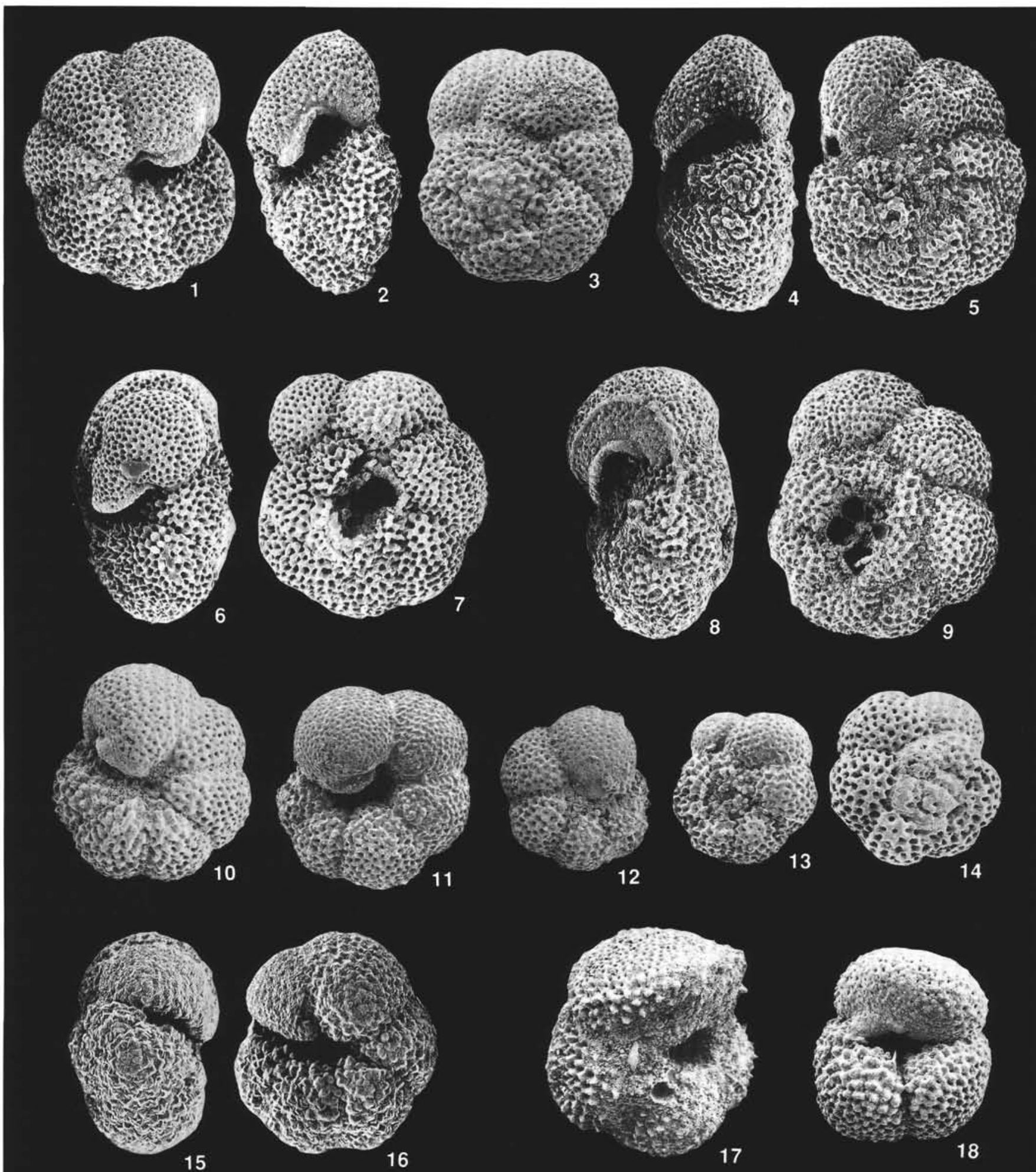

Plate 8. 1-5. Paragloborotalia kugleri; (1-2) Sample 130-803D-35X-5, 50-52 cm (first occurrence), $\times 150$; (3) Sample 130-803D-35X-5, 50-52 cm (first occurrence), $\times 150$; (4-5) Sample 130-803D-35X-3, 47-49 cm, $\times 150$. 6-16. Paragloborotalia pseudokugleri; (6-7) Sample 130-803D-35X-CC, $\times 150$; (8-9) Sample 130-803D-36X-CC, ×150; (10) Sample 130-803D-36X-CC, $\times 150$; (11) Sample 101-628A-17H-3, 100-102 cm, x150; (12) Sample 101-628A-16H-5, 100-102 cm, ×150; (13) Sample 101-628A-16H-CC, x150; (14) Sample 130-803D-39X-CC (first occurrence), $\times 150$; (15-16) Sample 130-803D-39X-CC (first occurrence), $\times 150$. 17-18. Globoquadrina dehiscens; (17) Sample 130-803D-35X-3, 47-49 cm (first occurrence), $\times 100$; (18) Sample 130-803D-35X-1, 50-52 $\mathrm{cm}, \times 100$. 


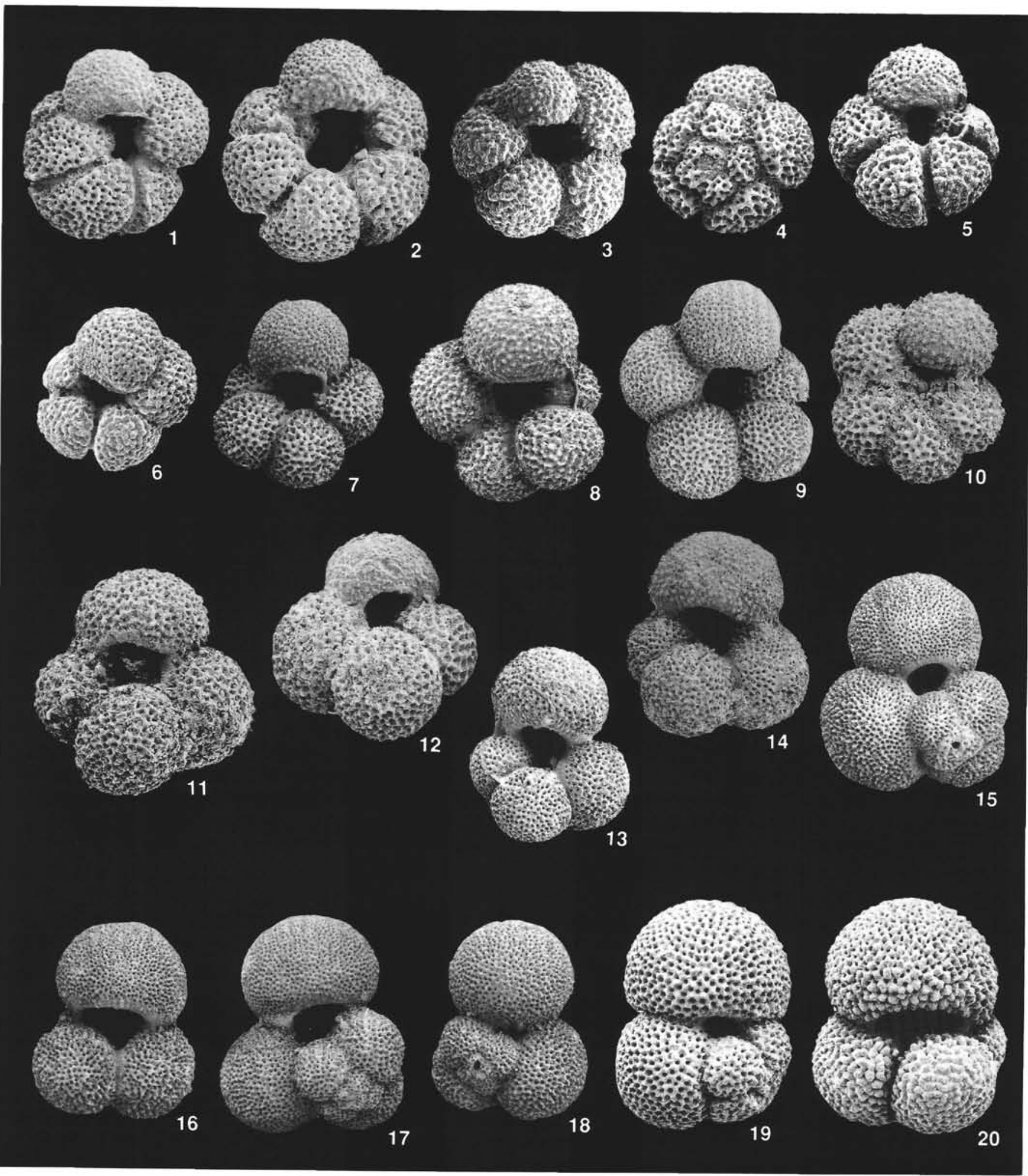

Plate 9. 1-6. Globigerina angulisuturalis; (1) Sample 101-628A-16H-3, 100-102 cm, $\times 150$; (2) Sample 101-628A-16H-3, 100-102 cm, $\times 150$; (3) Sample 130-803D-43X-1, 49-51 cm, ×150; (4) Sample 101-628A-16H-3, 100-102 cm, $\times 150$; (5) Sample 101-628A-25X-2, 12-14 cm (first occurrence), $\times 150$; (6) Sample 130-803D-47X-5, 48-50 cm (first occurrence), $\times 150$. 7-10. Globigerina ciperoensis; (7) Sample 101-628A-19H-3, 100-102 cm, $\times 100$; (8) Sample 101-628A18H-5, 100-102 cm, ×150; (9) Sample 101-628A-16H-3, 100-102 cm, x100; (10) Sample 101-628A-19H-1, 100-102 cm, ×150. 11-12. Globigerina ouachitensis; (11) Sample 101-628A-29X-2, 30-32 cm, $\times 150$; (12) Sample 101-628A-23X-CC, $\times 150$. 13-14. Globigerina praebulloides; (13) Sample 101-628A-18H-CC, $\times 100$; (14) Sample 101-628A-16H-5, 100-102 cm, $\times 100 . \quad 15-20$. Globigerinoides primordius; (15) Sample 101-628A-16H-1, 100-102 cm, $\times 70$; (16) Sample 101-628A-16H-1, 100-102 cm, $\times 70$; (17) Sample 101-628A-24X-1, 100-102 cm (first occurrence), $\times 70$; (18) Sample 101-628A-24X-1, 100-102 $\mathrm{cm}$ (first occurrence), $\times 70$; (19) Sample 130-803D-35X-1, 50-52 cm (first occurrence), $\times 100$; (20) Sample 130-803D-35X-1, 50-52 cm (first occurrence), $\times 100$. 